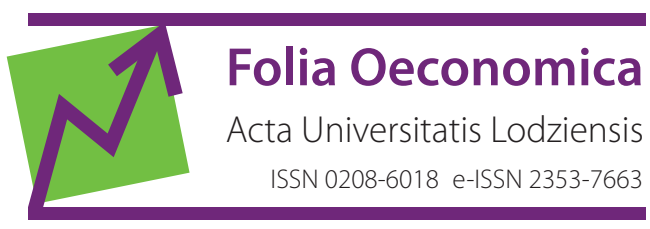

www.czasopisma.uni.lodz.pl/foe/

6(345) 2019

DOI: http://dx.doi.org/10.18778/0208-6018.345.02

\begin{abstract}
Anna Dyhdalewicz
Politechnika Białostocka, Wydział Inżynierii Zarządzania, Katedra Finansów i Rachunkowości

a.dyhdalewicz@pb.edu.pl
\end{abstract}

\author{
Renata Gmińska \\ Wyższa Szkoła Bankowa w Gdańsku, Wydział Finansów i Zarządzania, Katedra Finansów \\ gminscy@poczta.onet.pl
}

\title{
Etyka zawodowa księgowych z perspektywy studentów - prezentacja wyników badań ankietowych
}

Streszczenie: Etyka zawodowa to zbiór zasad i norm określających, w jaki sposób, z moralnego punktu widzenia, powinni zachowywać się przedstawiciele określonego zawodu. Kodeksy etyki stanowią narzędzie rozwinięcia zasad i wartości etycznych zaadaptowanych do konkretnych grup zawodowych, w tym zawodowych księgowych. Od kilku lat istnieje Kodeks zawodowej etyki w rachunkowości (KZEwR), przyjęty przez Stowarzyszenie Księgowych w Polsce. Według niego do podstawowych pryncypiów osób zajmujących się rachunkowością zalicza się uczciwość, obiektywizm, zawodowe kompetencje i należytą staranność, zachowanie tajemnicy informacji, profesjonalną postawę. Problemem badawczym jest próba odpowiedzi na pytanie: „Czy indywidualne zasady i wartości etyczne studentów są zbieżne z zasadami etycznymi wspólnoty zawodowej księgowych, które przedstawia KZEwR?". Celem artykułu jest identyfikacja moralnych i potencjalnie nieetycznych zachowań wśród studentów rachunkowości w kontekście zasad etycznych KZEwR. Dla osiągnięcia celu publikacji przeprowadzono badanie empiryczne. W procesie badawczym posłużono się badaniem pilotażowym z wykorzystaniem techniki PAPI. W opracowaniu wyników badań ankietowych wykorzystano metody ilościowe. Jak wynika z analiz, studenci wskazali na ogólne, powszechnie znane wartości etyczne. Jednak nie zawsze indywidualne zachowania studentów są zgodne z tym, co uważa się za właściwe i etyczne według standardów środowiska zawodowego księgowych. Wyraźnie daje się zauważyć, że studenci kierują się własnymi zasadami etycznymi, nawet jeśli naruszają prawo, podejmują wybory przez pryzmat osobistego interesu. Decydujące znaczenie w ich postępowaniu odgrywają czynniki endogeniczne. Uzyskane wyniki badań ujawniają skłonność części ankietowanych do różnego rodzaju działań nieetycznych, zagrażających realizacji ogólnych zasad etyki w rachunkowości, zarówno wśród osób zamierzających pracować, jak i deklarujących staż w zawodach księgowych.

Słowa kluczowe: etyka zawodowa, Kodeks zawodowej etyki w rachunkowości, rachunkowość, deontologiczna etyka biznesu

JEL: A12, M40, M41 


\section{Wprowadzenie}

Wiek XX zaowocował tworzeniem norm etycznych w zawodach związanych z finansami i rachunkowością. Rachunkowość, jako system informacyjny przedsiębiorstwa, powinna przedstawiać wierny i rzetelny obraz rzeczywistości gospodarczej oraz osiągnięć jednostki gospodarczej. Wiarygodność informacji dostarczanych przez rachunkowość wyznacza jej twórca - księgowy, odpowiedzialny za prowadzenie ksiąg rachunkowych i sporządzane na ich podstawie sprawozdanie finansowe, a także biegli rewidenci badający sprawozdanie i potwierdzający jego wiarygodność. Nadużycia i bankructwa wielu dużych spółek giełdowych, które zaskoczyły gospodarkę światową i przyciągnęły uwagę opinii publicznej, były między innymi efektem odejścia od zasad etyki zawodowej osób działających w obszarze rachunkowości i w dziedzinach pokrewnych. Negatywne praktyki nie wynikają tylko z elastycznych regulacji rachunkowości i możliwości wyboru wariantowych rozwiązań - dylematy etyczne mogą dotyczyć także osoby świadczącej usługi w zakresie rachunkowości (Maruszewska, 2014: 112). Świadome i celowe zniekształcanie informacji finansowych, zmierzające do osiągnięcia korzyści materialnych, podważyło wiarygodność raportów finansowych ogólnego przeznaczenia. Jednocześnie spowodowało spadek zaufania społecznego do postaw i zachowań osób zawodowo zajmujących się rachunkowością, w tym biegłych rewidentów, oraz do rezultatów ich pracy. Oszustwa księgowych powszechnie utożsamiano z zespołem zjawisk określanych mianem „rachunkowości kreatywnej” (Kutera, Hołda, Surdykowska, 2006: 15).

Etyka sprzyja tworzeniu w otoczeniu gospodarczym zaufania do zawodu księgowego oraz dodatkowo uwiarygadnia dane pochodzące z rachunkowości (Godlewska, Fołta, 2017: 425). Zaufanie, zdaniem F. Wali (2016: 9), stanowi najbardziej syntetyczny efekt etyki zawodowej w rachunkowości. Ważne jest zaufanie do każdej osoby działającej w obszarze rachunkowości lub w dziedzinach pokrewnych, to jest do jej postaw i zachowań, a równocześnie do rezultatów jej pracy, które są wykorzystywane przez liczną grupę interesariuszy do podejmowania racjonalnych decyzji gospodarczych. Zdaniem K. Sawickiego (2013: 582) coraz większego znaczenia nabiera problematyka etyki osób odpowiedzialnych za tworzenie informacji finansowych i informowanie o przypadkach naruszenia wymogów etycznych.

$\mathrm{Na}$ świecie i w Polsce środowiska zawodowych księgowych, w tym biegłych rewidentów, aspirujące do statusu zawodów zaufania publicznego, ustanawiają wymogi etyczne wyznaczające standardy postępowania (Micherda, Świetla, 2013: 125). Efektem działań międzynarodowego gremium rachunkowców są zapisy ogólnych zasad etycznego postępowania i zachowań w Kodeksie zawodowej etyki w rachunkowości IFAC, uchwalonym z inicjatywy Międzynarodowej Federacji Księgowych (International Federation of Accountants - IFAC). Również Komisja Zasad Etyki i Profesjonalizmu Zawodu Księgowego Rady Naukowej Stowarzyszenia Księgowych w Polsce opracowała Kodeks zawodowej etyki w rachunkowości (KZEwR), przy- 
jęty w 2007 roku przez SKwP. Podstawowe obszary ujęte w KZEwR to: kompetencje zawodowe i wysoka jakość pracy, niezależność zawodowa, odpowiedzialność za przygotowywane i prezentowane informacje z zakresu rachunkowości, zasady postępowania $\mathrm{w}$ relacjach z osobami, jednostkami i instytucjami powiązanymi z nią zawodowo, a także w przypadku sporu i sprzeczności interesów. Kodeks ten prezentuje także zasady postępowania księgowych w sytuacjach szczególnych jednostki prowadzącej rachunkowość lub jednostki usługowo prowadzącej rachunkowość, zachowania tajemnicy zawodowej oraz właściwego oferowania usług z tej dziedziny.

W przedstawionym kontekście kluczowego znaczenia nabiera problematyka zachowań i wartości moralnych osób zajmujących się rachunkowością i jej systemem informacyjnym, zgodnie z przyjętymi w środowisku normami i zasadami etyki. Jest to zagadnienie złożone, trudne i wysoce dyskusyjne. Przestrzeganie zasad etyki stanowi gwarancję utrzymania wysokiego statusu społecznego tych osób, a odbiorcom informacji zapewnia wymaganą jakość sprawozdań finansowych (Derlukiewicz, 2014: 306). Zachowania osoby zajmującej się rachunkowością zależą od (Karmańska, 2016: 36):

1) czynników egzogenicznych, wynikających z różnego rodzaju kodeksów, norm prawnych opracowanych przez ekspertów z różnych dziedzin,

2) czynników endogenicznych, związanych z wewnętrznym (osobowym) kodeksem uwarunkowanym wychowaniem, środowiskiem i otoczeniem, w którym kształtuje się osobowość i utrwalają pewne cechy charakteru.

Promowanie zasad etyki jest ważne nie tylko w zawodach wykonywanych w dziedzinie rachunkowości, ale również wśród młodzieży akademickiej (Voss, 2016: 141). W przypadku studentów - przyszłych księgowych - należy poznać ich poglądy i przekonania moralne, które są bardzo istotne zwłaszcza tam, gdzie w grę wchodzą transakcje finansowe lub decyzje o znaczących skutkach społecznych. W związku z tym problemem badawczym należy odpowiedzieć na pytanie: „Czy indywidualne zasady i wartości etyczne studentów są zbieżne $\mathrm{z}$ zasadami etycznymi wspólnoty zawodowej księgowych, które przedstawia KZEwR?".

Celem artykułu jest identyfikacja moralnych i potencjalnie nieetycznych zachowań wśród studentów rachunkowości w kontekście zasad etycznych KZEwR. Zgodnie z tym kodeksem do podstawowych pryncypiów osób zajmujących się rachunkowością zalicza się uczciwość, obiektywizm, zawodowe kompetencje i należytą staranność, zachowanie tajemnicy informacji oraz profesjonalną postawę.

Dla osiągnięcia celu artykułu przeprowadzono badanie empiryczne. W procesie badawczym posłużono się badaniem pilotażowym z wykorzystaniem techniki PAPI. Do opracowania wyników badań ankietowych wykorzystano metody ilościowe. W ocenie przekonań moralnych przyjęto, że indywidualne wartości, zgodne ze wzorcami zawodowymi odnoszącymi się do wszystkich księgowych, zasługują na uznanie i ocenę pozytywną (zachowanie etyczne moralnie dobre). I odwrotnie - indywidualne wartości niezgodne ze wzorcami zawodowymi oznaczają zachowanie nieetyczne (moralnie złe), niezgodne z przyjętymi w kodeksie zasadami etyki. 
Jako metodę badawczą zastosowano również przegląd literatury przedmiotowej i analizę treści wybranego piśmiennictwa z zakresu etyki biznesu, rachunkowości i etyki zawodowej w rachunkowości.

\section{Etyka zawodowa księgowych na tle normatywnej etyki biznesu}

Jak podkreśla P. Pratley (1998: 12): „Etyka jest gałęzią filozofii. Przedmiotem jej dociekań jest badanie zarówno moralnych, jak i niemoralnych zachowań w celu wyrobienia sobie uzasadnionych sądów oraz wypracowania odpowiednich rekomendacji”. Według G. Szulczewskiego (2012: 149): „Etyka zajmuje się oceną decyzji człowieka i dlatego w sposób konieczny wkracza w pole gospodarki”.

„Na przecięciu” etyki jako działu filozofii praktycznej oraz działalności menedżerskiej związanej głównie z gospodarką ukształtowała się etyka biznesu. Jako odrębna dyscyplina naukowa powstała w latach siedemdziesiątych XX wieku, jednak historia rozważań nad etycznymi problemami gospodarowania jest tak długa jak historia ludzkiej działalności (Chwistecka-Dudek, 2014: 11). Przedmiotem etyki biznesu jest ocena i określenie standardów moralnych przystających do konkretnej sfery współczesnej działalności gospodarczej. Jak zauważa H. Hiż, etyka biznesu musi być praktyczna, łączyć wymogi moralne z dbałością o interes przedsiębiorstwa jako strategicznego podmiotu biznesu (za: Zadroga, 2009: 27). Etyka biznesu, rozumiana jako zespół norm uznawanych w świecie biznesu, obejmuje w sensie pozytywnym zespół wartości i norm uznawanych i respektowanych, a w sensie negatywnym naruszanych - w świecie biznesu, w jego mentalności i działaniu. Jako szczegółowa dyscyplina etyczna, zajmująca się określoną kategorią działań człowieka, wymaga ona nie tylko bliskiego kontaktu z własnym przedmiotem, ale także z wynikami badań empirycznych podejmowanych przez szczegółowe nauki społeczne, w których występują w szerszym lub węższym zakresie wątki etyczne.

Kwestie moralne stojące u podstaw określonych zachowań dają się często przedstawić jako pewien dylemat. Wybory moralne nierzadko są bolesne, stwarzają zarówno pozytywne, jak i negatywne możliwości. Ponadto cechy te nie poddają się łatwej ocenie, ponieważ postępowanie ludzi warunkują odmienne cele, które mogą prowadzić do różnych standardów moralnych (Pratley, 1998: 13).

Normatywna etyka biznesu zajmuje się (Chwistecka-Dudek, 2014: 29):

1) konstruowaniem i uzasadnianiem systemów moralnych, które ich twórcy uważają za wartościowe lub słuszne; ,Jest to więc refleksja nad wartościami, normami i wzorcami, z których buduje się zgodny wewnętrzny system etyczny" (Zadroga, 2009: 105); 
2) poszukiwaniem podstawowych zasad, z których można wyprowadzić sposoby oceny oraz normy szczegółowe, a także ich uzasadnieniem.

$\mathrm{W}$ jej ramach deontologiczna etyka biznesu przejawia się w postaci dobrowolnie i samodzielnie formułowanych zasad etycznych, skodyfikowanych uregulowań praktyki zawodowej (środowiskowej). Stąd etyka zawodowa jest zespołem zasad i norm określających, w jaki sposób, z moralnego punktu widzenia, powinni zachowywać się przedstawiciele określonego zawodu (Czarnecki, 2008: 16; Klimek, 2014: 192-193). Reguły obowiązujące przedstawicieli danego zawodu wzbudzają zaufanie środowiska i wzmacniają poczucie obowiązku zawodowego. Do zadań etyki zawodowej można zaliczyć głównie regulowanie stosunków wewnątrz grupy zawodowej oraz przedstawicieli zawodu do przedmiotu pracy, podnoszenie prestiżu danej grupy zawodowej, krzewienie i egzekwowanie wymogów moralności zawodowej, a także ochronę przed szczególnie zagrażającymi niebezpieczeństwami moralnymi i pokusami, przed możliwością nadużyć wiążących się z charakterem wykonywanej pracy (Wołoszyn-Spirka, Krause, 2012: 92-93). Normy postępowania powstają z inicjatywy określonych środowisk zawodowych, przedsiębiorstw, instytucji, w postaci uporządkowanych zestawień, czyli kodeksów. Od tak rozumianej etyki zawodowej należy odróżnić moralność zawodową, pojmowaną jako postępowanie danej grupy zawodowej oceniane ze względu na kryteria moralne.

Za deontologiczną etyką, promowaną przez współczesną etykę biznesu, przemawia wiele argumentów. Według W. Gasparskiego kodeks, jeśli jest przestrzegany, zmniejsza przypadki korupcji, defraudacji i innych złych praktyk, zwiększa zaufanie kontrahentów, partnerów i klientów, lojalność pracowników oraz reputację firmy. Ponadto kodeksy etyczne zawierają nie tylko normy moralne odniesione do sytuacji występujących w organizacjach gospodarczych, administracyjnych czy w danym zawodzie, ale także nieujęte regulacjami prawnymi zalecenia, jak należy lub nie należy postępować we wskazanych sytuacjach (Gasparski, 2012: 233,238 ). Zaletą takiej formy regulacji w zawodzie jest możliwość uchwycenia sytuacji typowych, powtarzalnych, zasadniczych dla każdego rodzaju profesji. Jak pisze J. Brinkmann (2002: 162): ,[...] kodeksy rysują mapy spodziewanych konfliktów, oczekiwanych lub sugerowanych rozwiązań, i być może, przewidywalne sankcje". W opinii M. Rybak kodeksy etyczne pomagają w podejmowaniu decyzji etycznych oraz służą za podstawę przy rozwiązywaniu konfliktów etycznych (Rybak, 2004: 140). Kodeksy stanowią fundament do egzekwowania zachowań naruszających dobre imię zawodu czy konkretnego przedsiębiorstwa.

Zdaniem J. Klimka i A. Zadrogi wadą deontologicznej etyki jest to, że nie jest ona w stanie przewidzieć zmiennych warunków, w których człowiek zastosuje określone zasady. Stąd zasady w rzeczywistości mogą jedynie być postulatem, punktem odniesienia, ale nie mogą bezwzględnie wpływać na konkretne postawy moralne. $Z$ tego też wynika mała skuteczność w praktyce biznesu wszelkiego 
rodzaju kodeksów i negatywne opinie na ich temat (Zadroga, 2009: 108; Klimek, 2014: 183). Kodeksy akceptują i zachęcają do minimalizmu moralnego, promują pewne wartości, nie podpowiadają jednak rozwiązań w sytuacjach, gdy promowane wartości stają się konfliktowe (Rybak, 2004: 140; Karczewski, 2008: 157). Zdaniem J. Brinkmanna (2002: 162): „,...] ich odgórne wdrażanie prowadzi do sceptycyzmu, cynizmu, sprzeciwu i bojkotu zasad”. Według H. Chwisteckiej-Dudy (2014: 146): „Etyka zawodowa, której normy ograniczają się do zachowań i celów określonego zawodu, jest pewną wersją relatywizmu etycznego", a potrzeba formułowania kodeksów pojawia się w ramach zawodów, które przeżywają kryzys. Często wartości i normy postępowania zawarte w kodeksach są na wysokim poziomie ogólności, co sprawia, że zarzuca się im ogólnikowość i banalność (Lewicka-Strzałecka, 1999: 25).

Ogólnie kodeksy etyki w biznesie odwołują się do osobistego poczucia odpowiedzialności za podejmowane działania, świadomości społecznych konsekwencji podejmowanych decyzji gospodarczych, potrzeby uczciwego prowadzenia działań biznesowych, co oznacza akceptowanie systemu wysokich wartości moralnych i etycznych. Reasumując zalety i wady etyki kodeksowej, można stwierdzić za A. Kuzior (2017: 83), że „[...] kodeksy etyczne nie są zagrożeniem, lecz raczej dopełnieniem etyki indywidualnej”.

W literaturze z zakresu etyki biznesu podejmuje się dyskusję nad kwestią pochodzenia ocen moralnych. Według konsekwencjonalistów moralna ocena działania powinna opierać się na jego konsekwencjach (skutkach). Z kolei według deontologów ocena moralna nie opiera się na konsekwencjach działania, a raczej na jego wewnętrznej właściwości bądź niewłaściwości, bierze pod uwagę motywy i intencje. Istnieją sytuacje, w których pewne czyny są wewnętrznie niewłaściwe, nawet jeśli działanie wywołałoby najlepszy skutek (Micewski, Troy, 2007; Tyszka, Macko, 2012: 337).

Etyka rachunkowości stanowi odłam etyki biznesu, który można zdefiniować jako zespół wartości moralnych przyporządkowanych do czynności księgowych, czynności wspomagających zarządzanie, rozliczeń podatkowych i innych rozliczeń publicznoprawnych, usług z dziedziny rachunkowości w środowisku zawodowym rachunkowości. Według J. Godlewskiej i T. Fołty (2017: 425): „Etyka w rachunkowości to nic innego jak etyka człowieka pracującego w księgowości”. Etyka jest wsparciem dla prawa bilansowego, gdyż normy prawne ustalają tylko minimum wymagań moralnych. Ma ona na celu kształtowanie refleksyjnej postawy człowieka, jego powinności moralnych wobec problematycznych sytuacji zawodowych. Nie można mówić o wiarygodnych i rzetelnych danych pochodzących z rachunkowości, kiedy ludzie nie będą stosować się do ogólnie przyjętych norm i wartości etycznych. Jak pisze P. Jaijairam (2017: 1): „Obecny wiek informacji i świat biznesu wymaga od księgowego zachowania przejrzystości i dokładnego raportowania finansowego. Dlatego księgowi, którzy są odpowiedzialni za spo- 
rządzanie dokładnych, zwięzłych i terminowych sprawozdań finansowych, muszą przestrzegać najwyższych standardów etycznej odpowiedzialności”.

W Polsce wyznacznikiem standardów etycznych osób zawodowo związanych z rachunkowością jest opublikowany w 2007 roku Kodeks zawodowej etyki w rachunkowości wydany przez Komisję Zasad Etyki i Profesjonalizmu Zawodu Księgowego Rady Naukowej Stowarzyszenia Księgowych w Polsce. Jest on wynikiem wieloletniej pracy szerokiego grona wybitnych specjalistów i autorytetów reprezentujących środowisko naukowe oraz praktyków życia gospodarczego z dziedziny rachunkowości (Derlukiewicz, 2014: 310; Karmańska, 2016: 9). Zawód z dziedziny rachunkowości wymaga umiejętności tworzenia rzetelnego obrazu dokonań jednostki oraz zdolności analitycznego wykorzystywania powszechnie akceptowanych metod i standardów rachunkowości oraz zasad dobrej praktyki (Kodeks zawodowej etyki w rachunkowości, 2007: 18). Zdaniem E. Maruszewskiej (2014: 113): „Bez profesjonalizmu opartego na etyce zawodowej, rachunkowość nie gwarantuje wiarygodności informacji [...]".

Według KZEwR (2007: 17) zasady etyki to „moralne ramy wykonywania zawodu w dziedzinie rachunkowości”. Kodeks ten z punktu prawnego nie jest obowiązkowy, jednak osoby zajmujące się rachunkowością mają moralny obowiązek przestrzegania zasad w nim ujętych (Zuchewicz, 2008: 557; Lipińska, 2016: 231). Zakres podmiotowy kodeksu odnosi się do wszystkich osób zajmujących się rachunkowością, zarówno jednostek usługowo prowadzących rachunkowość, jak i osób fizycznych zajmujących się rachunkowością w jednostce oraz każdej innej osoby powiązanej z rachunkowością przez naukę, dydaktykę lub inne formy działalności zawodowej. Treść kodeksu obejmuje zasady i wartości etyczne oraz profesjonalne istotne dla osób zawodowo zajmujących się rachunkowością i dziedzinami pokrewnymi oraz wspiera realizację funkcji rachunkowości. Osoby zajmujące się rachunkowością powinny cechować się: obowiązkowością, uczciwością, fachowością, systematycznością, poczuciem odpowiedzialności, lojalnością wobec właściciela i kierownictwa jednostki (Voss, 2016: 135). Etyczne normy zawodowe, które zostały zdefiniowane w KZEwR, dotyczą kompetencji zawodowych, wysokiej jakości pracy, niezależności zawodowej, odpowiedzialności za przygotowywanie i prezentowanie informacji z zakresu rachunkowości, postępowania w relacjach z jednostkami z otoczenia oraz w sytuacjach szczególnych, zachowania tajemnicy służbowej i oferowania usług z tej dziedziny (Żuraw, 2012: 127-128; Garstka, 2014: 64). Z pewnością każdy zawód związany z finansami powinien kojarzyć się z najwyższymi kompetencjami i być gwarantem odpowiedzialności, wysokich walorów moralnych, a także urzeczywistniać ideę uczciwej, rzetelnej i profesjonalnej działalności (Kodeks zawodowej etyki w rachunkowości, 2007: 5). Według A. Karmańskiej Kodeks zawodowej etyki w rachunkowości jest instrumentem informowania świata biznesu o zasadach etyki w niej obowiązujących. Spełnia on dwie ważne funkcje (Karmańska, 2007: 397-398): 
1) określa zbiór zasad i wytycznych codziennego postępowania zawodowego dla osób zajmujących się rachunkowością,

2) wspomaga menedżerów w tworzeniu programów etycznych.

Jednak skuteczność kodeksu jako regulatora zachowań uzależniona jest od edukacji etycznej rozwijającej świadomość etyczną, że wizerunek zawodu kształtowany jest przez etyczne postępowanie zawodowych księgowych, a działanie nieetyczne nigdy nie leży w interesie podmiotu gospodarczego czy też osoby zajmującej się rachunkowością.

\section{Etyka w rachunkowości w badaniach empirycznych}

Skandale korporacyjne, oszustwa i bankructwa firm, kryzys finansowo-ekonomiczny lat 2008-2009 wywołane brakiem etyki w sferach finansów i rachunkowości spowodowały zainteresowanie naukowców i praktyków biznesu kwestiami etycznymi, również w obszarze rachunkowości, co z kolei poskutkowało rozwojem badań w tym zakresie. Metaanalizy polskiej myśli naukowej traktującej o problematyce etyki rachunkowości dokonała M. Nowak (2018: 93-104). Prezentując poglądy na ten temat w piśmiennictwie monograficznym, wskazała między innymi na (Nowak, 2018: 99-101):

1) etykę rachunkowości jako pewien specyficzny rodzaj etyki zawodowej, odnoszący się wprost do profesji księgowego: akcentowanie przede wszystkim konieczności zachowywania norm, działanie zgodnie z prawem i kodeksami etyki - jako paradygmat deontologiczny i legalistyczny punkt widzenia na etykę rachunkowości;

2) konieczność posiadania przez księgowych pewnych przymiotów - pogląd ten jest odzwierciedleniem podejścia wobec etyki rachunkowości przyjmowanego w teoriach cnoty;

3) istotność wpływu etyki na „produkty finalne” rachunkowości: jakość sprawozdań finansowych, wiarygodność informacji tworzonych w rachunkowości oraz odpowiedzialność księgowych, podkreślanie roli etyki rachunkowości w efektywności ekonomicznej przedsiębiorstw, użyteczności informacji dla ich odbiorców, spełniania ich preferencji informacyjnych oraz społecznej roli rachunkowości - jako paradygmat utylitarystyczny i aplikacyjny.

Badania nad etyką w rachunkowości, z uwagi na ich podmiot, można podzielić na trzy grupy:

1) badania empiryczne wśród praktyków rachunkowości: zarówno menedżerów, jak i pracowników zatrudnionych w działach finansowo-księgowych;

2) badania empiryczne wśród młodzieży akademickiej;

3) badania empiryczne zarówno wśród praktyków rachunkowości, jak i młodzieży akademickiej; interesujące są tutaj studia porównawcze odpowiedzi 
na pytania udzielone przez doświadczonych zawodowych księgowych i osoby niedoświadczone, studiujące rachunkowość i kierunki pokrewne.

Tło rozważań badaczy rachunkowości to etyka w powiązaniu z regulacjami prawnymi, normami i standardami etycznymi, aspekty psychologiczne, socjologiczne, ekonomiczne i filozoficzne. W obszarze metodycznym wykorzystano zarówno badania jakościowe, jak i ilościowe, w tym oparte na danych uzyskanych głównie dzięki wykorzystaniu techniki ankietowej. Wśród metod pozwalających poznać wiedzę i reakcje respondentów na temat sposobu przestrzegania zasad etyki w rachunkowości na szczególną uwagę zasługuje wykorzystanie metody scenariuszy i studiów przypadków. Podstawowe znaczenie ma tutaj przedstawienie mogących zaistnieć w rzeczywistości dylematów związanych z rachunkowością i moralnością jednocześnie. Pokazanie wielowymiarowości praktyki, umożliwienie respondentom wczuwania się w autentyczne uwarunkowania w trakcie dokonywanych wyborów ma wyraźny walor poznawczy, nie tylko uczy wartości, lecz także wzbogaca ich wiedzę. Przegląd wybranych zagranicznych i krajowych badań empirycznych w obszarze etyki w rachunkowości przedstawiono w Tabeli 1.

Konkludując dotychczasowe rozważania, należy podkreślić rozległość możliwej do analizy i oceny problematyki etyki w rachunkowości oraz wielość luk badawczych w tym obszarze. Na gruncie rachunkowości i etyki zawodowej ważna jest potrzeba przejścia od myślenia przez pryzmat indywidualnych zasad w kierunku myślenia przez pryzmat norm wspólnoty księgowych.

Tabela 1. Wybrane badania empiryczne w obszarze etyki w rachunkowości

\begin{tabular}{|c|c|c|}
\hline Autor & Podmiot i cele badań & Kluczowe wnioski \\
\hline \multicolumn{3}{|c|}{ Badania zagraniczne } \\
\hline $\begin{array}{l}\text { Cagle, Baucus } \\
\text { (2006: 213-229) }\end{array}$ & $\begin{array}{l}\text { Podmiot: studenci kierunku finanse } \\
\text { korporacyjne (54 osoby) i studenci } \\
\text { MBA (32 osoby) na prywatnym } \\
\text { jezuickim uniwersytecie. } \\
\text { Cel: ustalenie wpływu nauczania } \\
\text { za pomocą studiów przypadków } \\
\text { na zdolność studentów do podejmo- } \\
\text { wania etycznych decyzji oraz tego, } \\
\text { czy ostatnie skandale związane } \\
\text { z etyką, dotyczące takich podmio- } \\
\text { tów jak np. Enron, Tyco, Adelphia, } \\
\text { mogły wpłynąć na postrzeganie } \\
\text { przez studentów znaczenia etyki } \\
\text { i jej rozpowszechnienie w biznesie. }\end{array}$ & $\begin{array}{l}\text { Badanie wykazało, że nauczanie } \\
\text { poprawia umiejętność rozumowa- } \\
\text { nia etycznego i pozytywnie wpływa } \\
\text { na etyczne podejmowanie decyzji. } \\
\text { Studia przypadków skandali etycz- } \\
\text { nych pozytywnie wpływają na } \\
\text { postrzeganie etyki przez studentów } \\
\text { kierunku finanse (którzy są } \\
\text { także zobowiązani do podjęcia zajęć } \\
\text { z filozofii, religii i społeczeństwa), } \\
\text { zmniejszając liczbę skłonnych } \\
\text { do tolerowania nieetycznego lub } \\
\text { budzącego wątpliwości zachowa- } \\
\text { nia. Wyniki badań wśród studentów } \\
\text { kierunku finanse i studentów MBA } \\
\text { (którzy nie podejmują dodatkowych } \\
\text { szkoleń w tym obszarze) nie wyka- } \\
\text { zały istotnych różnic. }\end{array}$ \\
\hline
\end{tabular}




\begin{tabular}{|c|c|c|}
\hline Autor & Podmiot i cele badań & Kluczowe wnioski \\
\hline $\begin{array}{l}\text { Emerson, } \\
\text { Conroy, Stanley } \\
(2007: 73-87)\end{array}$ & $\begin{array}{l}\text { Podmiot: praktycy rachunkowości } \\
\text { (520 osób) i studenci interdyscy- } \\
\text { plinarnych specjalności (613 osób) } \\
\text { z dwóch uniwersytetów stanów po- } \\
\text { łudniowych Ameryki (prywatnego } \\
\text { i publicznego). } \\
\text { Cel: sprawdzenie etycznej strony } \\
\text { podejmowanych decyzji na podsta- } \\
\text { wie scenariuszy przypominających } \\
\text { sytuację Enronu i WorldCom. }\end{array}$ & $\begin{array}{l}\text { Etyczne postawy i wybory prakty- } \\
\text { ków rachunkowości nie różnią się } \\
\text { znacznie od postaw studentów z ob- } \\
\text { szaru różnych specjalności, nawet } \\
\text { dla konkretnych „,sztuczek księgo- } \\
\text { wych”. Praktykujący księgowi czę- } \\
\text { ściej akceptowali scenariusze róż- } \\
\text { nych „,sztuczek księgowych”, które } \\
\text { wiązały się z krzywdą osób fizycz- } \\
\text { nych, oraz rozwiązania dozwolone } \\
\text { prawem, ale etycznie wątpliwe. }\end{array}$ \\
\hline $\begin{array}{l}\text { Elias, Farag } \\
(2010: 269-281)\end{array}$ & $\begin{array}{l}\text { Podmiot: studenci studiów licen- } \\
\text { cjackich i magisterskich dwóch } \\
\text { uczelni w zachodnich stanach USA } \\
\text { (213 osób). } \\
\text { Cel: zbadanie zachowań etycznych } \\
\text { studentów rachunkowości, uwzględ- } \\
\text { niając to, w jaki sposób postrze- } \\
\text { gają oni działania oszukańcze we- } \\
\text { wnątrz i na zewnątrz sali lekcyjnej } \\
\text { oraz przyjmując jako determinan- } \\
\text { tę zachowań miłość do pieniędzy. } \\
\text { Studenci zostali zaklasyfikowani } \\
\text { zgodnie z zamiłowaniem do pienię- } \\
\text { dzy jako „czciciele pieniędzy” (mo- } \\
\text { ney worshippers), „czujący wstręt } \\
\text { do pieniądza” (money repellents) lub } \\
\text { „miłośnicy pieniędzy” (money ad- } \\
\text { mirers). }\end{array}$ & $\begin{array}{l}\text { Studenci rachunkowości postrze- } \\
\text { gają działania oszustów na sali lek- } \\
\text { cyjnej jako bardziej nieetyczne niż } \\
\text { poza nią. Postrzeganie oszukiwa- } \\
\text { nia jest silnie związane z miłością } \\
\text { do pieniądza. Zwolennicy pieniądza } \\
\text { postrzegają oszustwa jako bardziej } \\
\text { etyczne, a money repellents jako } \\
\text { bardziej nieetyczne. }\end{array}$ \\
\hline $\begin{array}{l}\text { Fischer, } \\
\text { Marsh, Hunt } \\
(2013: 93-104)\end{array}$ & $\begin{array}{l}\text { Podmiot: praktycy posiadający cer- } \\
\text { tyfikat Certified Public Accounting } \\
\text { (CPA) (803 osób) i studenci studiu- } \\
\text { jący, aby uzyskać CPA (612 osób) } \\
\text { w regionie wschodniego Teksasu. } \\
\text { Cel: ocena różnic w zakresie wybo- } \\
\text { rów scenariuszy i etycznej strony } \\
\text { podejmowanych decyzji z obszarów } \\
\text { rachunkowości. }\end{array}$ & $\begin{array}{l}\text { Akceptacja przez studentów trans- } \\
\text { akcji księgowych była znacznie } \\
\text { ostrzejsza niż praktyków. Jednak } \\
\text { zarówno studenci, jak i praktycy } \\
\text { jednakowo ocenili i uznali prezen- } \\
\text { towane scenariusze rachunkowo- } \\
\text { ści za nieetyczne. Lata doświadcze- } \\
\text { nia zawodowego mają pozytywny } \\
\text { wpływ na etyczne wybory prakty- } \\
\text { ków w zakresie sporządzania spra- } \\
\text { wozdań finansowych. Większa ak- } \\
\text { ceptacja nieetycznych scenariuszy } \\
\text { wśród studentów może być powo- } \\
\text { dem zagrożenia rzetelnego prezen- } \\
\text { towania sytuacji ekonomicznej jed- } \\
\text { nostki. }\end{array}$ \\
\hline
\end{tabular}




\begin{tabular}{|c|c|c|}
\hline Autor & Podmiot i cele badań & Kluczowe wnioski \\
\hline $\begin{array}{l}\text { Gurvitsh, } \\
\text { Alver, Alver } \\
\text { (2017: 79-95) }\end{array}$ & $\begin{array}{l}\text { Podmiot: absolwenci i studenci kie- } \\
\text { runków rachunkowość i zarządzanie } \\
\text { na Tallinn University of Technology } \\
\text { oraz praktycy ( } 587 \text { ankiet). } \\
\text { Cel: ustalenie ważności etyki biz- } \\
\text { nesu i etyki zawodowej oraz okre- } \\
\text { ślenie ich miejsca w nowoczesnej } \\
\text { praktyce gospodarczej według stu- } \\
\text { dentów i praktyków w Estonii. }\end{array}$ & $\begin{array}{l}\text { Analiza odpowiedzi w kontekście } \\
\text { wieku, statusu, płci i specjalizacji. } \\
\text { Respondenci znają pojęcie etyki biz- } \\
\text { nesu, ale nie jest ona dla nich istot- } \\
\text { na. Ważność etyki wśród praktyków } \\
\text { jest większa niż wśród studentów, } \\
\text { znaczenie etyki wzrasta wraz z wie- } \\
\text { kiem, a etyka wśród zawodowych } \\
\text { księgowych jest istotniejsza niż } \\
\text { wśród ludzi biznesu. Badanie wska- } \\
\text { zuje na konieczność uwzględnienia } \\
\text { zagadnień dotyczących etyki bizne- } \\
\text { su i etyki zawodowej w programach } \\
\text { nauczania na uczelniach wyższych } \\
\text { oraz w świecie biznesu. }\end{array}$ \\
\hline \multicolumn{3}{|c|}{ Badania krajowe } \\
\hline $\begin{array}{l}\text { Karmańska } \\
\text { (2005: 138-165) }\end{array}$ & $\begin{array}{l}\text { Podmiot: pracownicy działów fi- } \\
\text { nansowo-księgowych średnich lub } \\
\text { dużych firm, krajowych i zagranicz- } \\
\text { nych uczestników programu pody- } \\
\text { plomowych studiów menedżerskich } \\
\text { i MBA w SGH (108 osób). } \\
\text { Cel: identyfikacja motywów nie- } \\
\text { etycznych zachowań osób zajmują- } \\
\text { cych się rachunkowością. }\end{array}$ & $\begin{array}{l}\text { Analiza odpowiedzi w kontek- } \\
\text { ście stażu pracy zawodowej. Osoby } \\
\text { ze stażem do } 10 \text { lat: naciski zarządu, } \\
\text { możliwość zarobienia dużych pie- } \\
\text { niędzy, brak bezpośredniej odpo- } \\
\text { wiedzialności za podjęte działania. } \\
\text { Zjawisko nieetycznego zachowania } \\
\text { bardzo powszechne. } \\
\text { Osoby ze stażem od } 10 \text { do } 20 \text { lat } \\
\text { - chęć ukrycia własnych błędów, } \\
\text { agresywne zachowania biznesowe, } \\
\text { niejednoznaczność przepisów pra- } \\
\text { wa; ze stażem } 21-30 \text { lat - zasada } \\
\text { „cel uświęca środki”, chęć przypo- } \\
\text { dobania się szefom, brak wzorców } \\
\text { etycznych, praktycznie nie obser- } \\
\text { wuje się potrzeby zachowań etycz- } \\
\text { nych. Groźba konsekwencji jako } \\
\text { hamulec działań nieetycznych. } \\
\end{array}$ \\
\hline $\begin{array}{l}\text { Kozak } \\
(2010: 54-59)\end{array}$ & $\begin{array}{l}\text { Podmiot: młodzież akademicka Wy- } \\
\text { działu Nauk Ekonomicznych i Za- } \\
\text { rządzania Uniwersytetu M. Koper- } \\
\text { nika w Toruniu ( } 278 \text { ankiet). } \\
\text { Cel: zbadanie skłonności studentów } \\
\text { do działań nieetycznych, poznanie } \\
\text { powodów uczciwego postępowania } \\
\text { oraz poznanie skojarzeń ankietowa- } \\
\text { nych ze słowem etyka. }\end{array}$ & $\begin{array}{l}\text { W grupie ankietowanych } 40 \% \text { było } \\
\text { skłonnych do działań nieetycznych, } \\
\text { a nawet niezgodnych z prawem, } \\
\text { w imię realizacji celów zawodo- } \\
\text { wych i materialnych. }\end{array}$ \\
\hline
\end{tabular}




\begin{tabular}{|c|c|c|}
\hline Autor & Podmiot i cele badań & Kluczowe wnioski \\
\hline $\begin{array}{l}\text { Piechocka-Kałużna } \\
\text { (2014: 443-456) }\end{array}$ & $\begin{array}{l}\text { Podmiot: księgowi, biegli rewidenci, } \\
\text { pracownicy naukowi. } \\
\text { Cel: badania dotyczyły kwestii pre- } \\
\text { zentacji prawdy w sprawozdaniach } \\
\text { finansowych, w tym obejmowa- } \\
\text { ły cząstkowe badania postrzegania } \\
\text { przez respondentów roli etyki w za- } \\
\text { pewnianiu wiarygodności wyników } \\
\text { prezentowanych w sprawozdaniach } \\
\text { finansowych. }\end{array}$ & $\begin{array}{l}\text { Zdaniem respondentów etyka, choć } \\
\text { jest nieodzownym elementem pracy } \\
\text { osób odpowiedzialnych za sprawoz- } \\
\text { dania finansowe, jest także narzę- } \\
\text { dziem służącym do tuszowania ne- } \\
\text { gatywnych skutków zaniechań osób } \\
\text { stanowiących prawo, unikających } \\
\text { przedstawienia jednoznacznych } \\
\text { rozwiązań (uregulowań) i wzięcia } \\
\text { za nie odpowiedzialności. }\end{array}$ \\
\hline $\begin{array}{l}\text { Karmańska } \\
(2016: 48-51)\end{array}$ & $\begin{array}{l}\text { Podmiot: studenci SGH (100 osób). } \\
\text { Cel: odpowiedź na pytania: „Co są- } \\
\text { dzą na temat etyki w rachunkowo- } \\
\text { ści?”, „Czy zauważają problem?”, } \\
\text { „Czy widzą rozwiązania ważne dla } \\
\text { jej krzewienia?”. }\end{array}$ & $\begin{array}{l}\text { Wypowiedzi w formie eseju wska- } \\
\text { zują, że „edukacja w obszarze ra- } \\
\text { chunkowości musi być skoncen- } \\
\text { trowana jednocześnie na trzech } \\
\text { specjalizacjach: przyszłych księgo- } \\
\text { wych, menadżerach i właścicielach- } \\
\text {-inwestorach”. }\end{array}$ \\
\hline $\begin{array}{l}\text { Voss } \\
\text { (2016: 142-162) }\end{array}$ & $\begin{array}{l}\text { Podmiot: pracownicy działów finan- } \\
\text { sowo-księgowych i biegli rewiden- } \\
\text { ci, będący członkami SKwP Oddział } \\
\text { w Bydgoszczy (118 ankiet). } \\
\text { Cel: określenie stopnia wykorzysta- } \\
\text { nia wzorców etycznych zawartych } \\
\text { w KZEwR przez polskich księgo- } \\
\text { wych oraz pokazanie czynników } \\
\text { wpływających na występowanie } \\
\text { zachowań nieetycznych. }\end{array}$ & $\begin{array}{l}\text { Około 70\% respondentów wska- } \\
\text { zało na występowanie zachowań } \\
\text { nieetycznych w pracy zawodowej. } \\
\text { Główne determinanty to wpływ } \\
\text { osób kierujących na podwładnych, } \\
\text { nacisk kadry kierowniczej na uzy- } \\
\text { skiwanie jak najlepszych wyników, } \\
\text { obawa przed utratą pracy. }\end{array}$ \\
\hline
\end{tabular}

Źródło: opracowanie własne

\section{Metodyka badań}

Badanie miało charakter pilotażowy i zostało przeprowadzone z wykorzystaniem techniki PAPI. Poprzedzało ono badanie główne i miało na celu weryfikację poprawności zastosowania narzędzi badawczych, ewentualnie grupy respondentów, służyło też ocenie poprawności metodycznej badania i poprawie jego jakości oraz wstępnemu rozpoznaniu wiedzy o badanym środowisku. Narzędziem badania był kwestionariusz ankietowy. Obejmował on pytania otwarte i zamknięte, w tym pytania z pięciostopniową skalą Likerta. Ankieta składała się z dwóch części. Pierwsza część obejmowała pytania pozwalające zbadać: skojarzenia studentów z pojęciem etyka, świadomość istnienia krajowych i międzynarodowych kodeksów etyki zawodowej w rachunkowości, skłonność do działań etycznych i nieetycznych, czynniki wpływające na ich zachowania. Druga część ankiety to metryczka zawierająca informacje o respondencie (stopień i kierunek studiów, staż pracy, wiek i płeć). 
Analizę uzyskanych ocen liczbowych, w ramach pytań z wykorzystaniem pięciostopniowej skali ocen Likerta, oparto na podstawowych miarach tendencji centralnej oraz rozproszenia i asymetrii ich rozkładu. W pozostałych pytaniach obliczono frakcje procentowe.

Anonimowe badanie ankietowe zostało przeprowadzone między grudniem 2017 a styczniem 2018 roku wśród studentów Wydziału Inżynierii Zarządzania Politechniki Białostockiej i Wyższej Szkoły Bankowej w Gdańsku, studiujących na kierunku lub specjalności finanse i rachunkowość. Przekazano 182 ankiety i otrzymano 164 prawidłowo wypełnione kwestionariusze. Charakterystykę próby badawczej przedstawia Tabela 2 .

Tabela 2. Charakterystyka próby badawczej

\begin{tabular}{|c|c|c|c|c|c|}
\hline Kierunek studiów & Liczebność & Udzial & Stopień studiów & Liczebność & Udzial \\
\hline $\begin{array}{l}\text { Finanse } \\
\text { i rachunkowość }\end{array}$ & 110 & $67,07 \%$ & $\begin{array}{l}\text { Studia pierwszego } \\
\text { stopnia }\end{array}$ & 36 & $21,95 \%$ \\
\hline Zarządzanie & 54 & $32,93 \%$ & Studia drugiego stopnia & 128 & $78,05 \%$ \\
\hline Pleć & Liczebność & Udzial & Tryb studiowania & Liczebność & Udzial \\
\hline Mężczyzna & 18 & $10,98 \%$ & Studia stacjonarne & 66 & $40,24 \%$ \\
\hline Kobieta & 146 & $89,02 \%$ & Studia niestacjonarne & 98 & $59,76 \%$ \\
\hline Staż pracy & Liczebność & Udzial & Wiek & Liczebność & Udzial \\
\hline Brak & 54 & $32,93 \%$ & \multirow[t]{2}{*}{$19-25$} & \multirow[t]{2}{*}{128} & \multirow[t]{2}{*}{$78,05 \%$} \\
\hline Do 6 miesięcy & 17 & $10,37 \%$ & & & \\
\hline $\begin{array}{l}\text { Od } 6 \text { miesięcy } \\
\text { do roku }\end{array}$ & 19 & $11,59 \%$ & $26-35$ & 31 & $18,90 \%$ \\
\hline \multirow[t]{2}{*}{ Powyżej roku } & \multirow[t]{2}{*}{74} & \multirow[t]{2}{*}{$45,12 \%$} & $36-50$ & 5 & $3,05 \%$ \\
\hline & & & Powyżej 50 & 0 & $0,00 \%$ \\
\hline
\end{tabular}

Źródło: opracowanie własne

Wśród 164 przebadanych było 110 studentów kierunku finanse i rachunkowość z Wyższej Szkoły Bankowej w Gdańsku (około 67\% ogółu badanych) oraz 54 studentów kierunku zarządzanie ze specjalnością Finanse i Rachunkowość z Politechniki Białostockiej (około 33\% ogółu respondentów). W grupie badanych:

1) dominowali studenci studiów drugiego stopnia (128 osób, około 75\% ogółu respondentów),

2) dominowały kobiety (146 osób, około 89\% ogółu badanych),

3) przeważali studenci w przedziale wiekowym 19-25 lat (128 osób, 78\% ogółu badanych),

4) studenci mieli zróżnicowany poziom doświadczenia zawodowego w rachunkowości, najwięcej osób deklarowało doświadczenie zawodowe powyżej roku (74 osoby, około 45\%) oraz jego brak (54 osoby, około 33\% ogółu ankietowanych). 


\section{Wyniki badań i dyskusja}

Zgodnie z KZEwR od osób zajmujących się rachunkowością, poza wiedzą i umiejętnościami zawodowymi, wymaga się poszanowania zasad etyki. Kodeks skierowany jest do wszystkich, którzy zawodowo zajmują się rachunkowością, a także innych osób powiązanych z rachunkowością przez naukę i dydaktykę. W pytaniu pierwszym kwestionariusza ankiety poproszono respondentów o podanie kilku skojarzeń z pojęciem etyka. Około $21 \%$ ankietowanych (34 osoby) nie udzieliło odpowiedzi na to pytanie. Pozostali najczęściej wymieniali elementarne wartości etyczne, takie jak: uczciwość, moralność, odpowiednie zachowanie, przestrzeganie zasad, reguł, postępowanie zgodne z sumieniem, z własnymi przekonaniami, wzorcami, normami, a także dodatkowe wartości, takie jak: kultura osobista, prawość, dobre obyczaje, ale też obiektywizm, bezstronność, rzetelność, profesjonalizm. Wiele osób kojarzyło etykę z religią, natomiast kilku respondentów wskazało na nieetyczne zachowania, takie jak korupcja i mobbing. Wskazane przez studentów ogólne wartości etyczne są powszechnie znane i akceptowane, uwzględniają zarówno własne osądy moralne (postępowanie zgodne z własnym sumieniem), jak i łączenie etyki z respektowaniem norm, wzorców. Zgodnie z KZEwR oczekuje się wykonywania pracy w sposób rzetelny, profesjonalny oraz działania w sposób kompetentny, praworządny, obiektywny i uczciwy. Wyróżnione przez studentów wartości etyczne w zasadzie „,mieszczą się” w realizacji ogólnych zasad etyki rachunkowości uznanych za niezbędne w pracy zawodowej.

Kolejne pytanie dotyczyło świadomości istnienia kodeksów informujących o zasadach, które zapewniają wykonywanie pracy z zakresu rachunkowości i rewizji finansowej w sposób rzetelny, profesjonalny i odpowiedzialny. Odpowiedzi respondentów ujęto w Tabeli 3.

SKwP czynnie promuje zasady KZEwR i profesjonalne zachowanie w środowisku osób związanych z rachunkowością. Oczekuje się więc, że podejmowanie pracy zawodowej sprzyja wzrostowi świadomości istnienia regulacji w zakresie etyki w rachunkowości. Studenci deklarujący staż zawodowy mogą w praktyce gospodarczej zaobserwować wdrożenie norm etycznych w tej dziedzinie, które dodatkowo wspierają wymagania określone w prawie bilansowym. Jak wynika z danych zawartych w Tabeli 3, prawie 55\% ankietowanych wskazało, że wie o istnieniu KZEwR. Porównanie odpowiedzi na pytanie wskazuje, że najwięcej stwierdzeń pozytywnych jest w grupach respondentów, którzy deklarują staż pracy. Zdecydowanie mniej pozytywnych odpowiedzi udzielono w zakresie kojarzenia kodeksu etyki, który obowiązywał wśród biegłych rewidentów (około $45 \%$ ) oraz międzynarodowego kodeksu IFAC (około 10\%). Może to wynikać z charakteru wykonywanych czynności księgowych $w$ ich pracy zawodowej. Z powyższych odpowiedzi nie można wprawdzie wnioskować o wdrożeniu w praktyce organizacji norm etycznych w rachunkowości, można jednak przypuszczać, że istnieją sformalizowane reguły etyczne czy też propagowanie zasad zawartych w krajowych kodeksach w przedsiębiorstwach, w których studenci zdobywali doświadczenie zawodowe. 


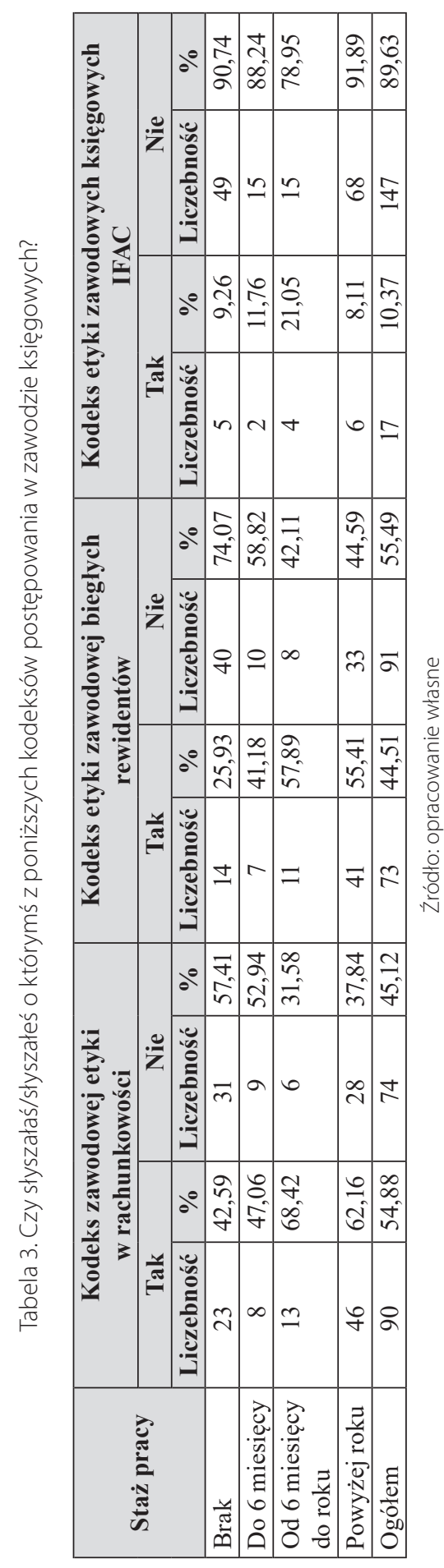


Profesjonalizm zawodowy jest elementem etycznej postawy. KZEwR podkreśla wartość odpowiednich kompetencji zawodowych i wysokiej jakości pracy. Zasada kompetencji zawodowych wymaga od osoby zajmującej się rachunkowością posiadania należytego przygotowania zawodowego, które zapewni wysoką jakość wykonywanej pracy. Jednocześnie kodeks zaznacza (2007: 25), że: „Uczciwość intelektualna oznacza, iż osoba zajmująca się rachunkowością nie może sprawiać wrażenia, że dysponuje wiedzą i doświadczeniem, których w rzeczywistości nie posiada [...]”. W związku z tym respondentów poproszono o odpowiedź na pytanie: „Czy podjęliby ryzyko otworzenia własnego biura rachunkowego mimo braku kwalifikacji zawodowych w rachunkowości i dziedzinach pokrewnych?”. Miało ono na celu sprawdzenie, czy studenci będą chcieli jednocześnie prowadzić działalność i postępować etycznie. Zestawienie udzielonych odpowiedzi przedstawia Tabela 4.

Tabela 4. Czy zaryzykowałabyś/zaryzykowałbyś otworzenie własnego biura rachunkowego, mając świadomość braku rzetelnej wiedzy i kompetencji zawodowych z dziedziny rachunkowości i obszarów powiązanych?

\begin{tabular}{|c|c|c|c|c|c|c|c|c|c|c|}
\hline \multirow{3}{*}{$\begin{array}{c}\text { Staż } \\
\text { pracy }\end{array}$} & \multicolumn{8}{|c|}{ Odpowiedzi } & \multirow{2}{*}{\multicolumn{2}{|c|}{ Ogólem }} \\
\hline & \multicolumn{2}{|c|}{ Tak } & \multicolumn{2}{|c|}{$\begin{array}{c}\text { Tak, pod } \\
\text { warunkiem } \\
\text { systematycz- } \\
\text { nego szkolenia }\end{array}$} & \multicolumn{2}{|c|}{\begin{tabular}{|c|} 
Tak, pod \\
warunkiem \\
zatrudnienia \\
osób z odpo- \\
wiednimi kwa- \\
lifikacjami \\
\end{tabular}} & \multicolumn{2}{|c|}{$\begin{array}{c}\text { Nie, powin- } \\
\text { nam/powinie- } \\
\text { nem nabrać } \\
\text { doświadczenia } \\
\text { zawodowego }\end{array}$} & & \\
\hline & $\begin{array}{c}\text { Liczeb- } \\
\text { ność }\end{array}$ & $\%$ & \begin{tabular}{|c|}
$\begin{array}{c}\text { Liczeb- } \\
\text { ność }\end{array}$ \\
\end{tabular} & $\%$ & $\begin{array}{c}\begin{array}{c}\text { Liczeb- } \\
\text { ność }\end{array} \\
\end{array}$ & $\%$ & \begin{tabular}{|c|} 
Liczeb- \\
ność
\end{tabular} & $\%$ & $\begin{array}{c}\text { Liczeb- } \\
\text { ność }\end{array}$ & $\%$ \\
\hline Brak & 1 & 1,85 & 7 & 12,96 & 13 & 24,07 & 33 & 61,11 & 54 & 100 \\
\hline $\begin{array}{l}\text { Do } 6 \text { mie- } \\
\text { sięcy }\end{array}$ & 1 & 5,55 & 3 & 16,67 & 5 & 27,78 & 9 & 50 & 18 & 100 \\
\hline $\begin{array}{l}\text { Od } 6 \text { mie- } \\
\text { sięcy } \\
\text { do roku }\end{array}$ & 0 & 0 & 1 & 5,26 & 2 & 10,53 & 16 & 84,21 & 19 & 100 \\
\hline $\begin{array}{l}\text { Powyżej } \\
\text { roku }\end{array}$ & 1 & 1,37 & 6 & 8,22 & 17 & 23,29 & 50 & 67,12 & 73 & 100 \\
\hline Ogółem & 3 & 1,83 & 17 & 10,37 & 37 & 22,56 & 107 & 65,24 & 164 & 100 \\
\hline
\end{tabular}

Źródło: opracowanie własne

Większość respondentów udzieliła odpowiedzi negatywnej, wskazującej na konieczność zdobycia doświadczenia zawodowego (107 osób, około 65\% ogółu). Należy przy tym zaznaczyć, że najwyższy odsetek osób był w grupie deklarującej staż od 6 miesięcy do roku (około 84\%) oraz powyżej roku (około $67 \%$ ). W pozostałych grupach studentów odpowiedź „Nie” stanowiła powyżej $50 \%$. Takie podejście należy ocenić jako zgodne z kodeksem. Oznacza ono, że ta grupa respondentów uzależnia prowadzenie usług w zakresie rachunkowości od posiadania niezbędnej wiedzy merytorycznej, zawodowych umiejętności 
i doświadczenia. Wybór określonego postępowania jest rezultatem ich indywidualnej oceny i reprezentowanych przez nich wartości. Jednak w przypadku wątpliwości dotyczących własnej wiedzy i zawodowych umiejętności takie ryzyko nie będzie przez nich podejmowane. Można to ocenić jako postępowanie w pewnym sensie prewencyjne, ograniczające potencjalne sytuacje nieetyczne.

Pozostała część ankietowanych studentów udzieliła odpowiedzi pozytywnej (57 osób, około 35\% ogółem), przy czym:

1) około $10 \%$ pod warunkiem systematycznego szkolenia, należy jednak podkreślić zagrożenie niewłaściwego wykonywania czynności zawodowych w trakcie zdobywania niezbędnej wiedzy;

2) około $23 \%$ pod warunkiem zatrudnienia osób z odpowiednimi kwalifikacjami, a więc uzyskania doradztwa i pomocy odpowiednich specjalistów, co dopuszcza kodeks;

3) około $2 \%$ podjęłoby ryzyko prowadzenia biura, mając świadomość braku wiedzy i kompetencji zawodowych, a to nie służy interesom zawodu i społeczeństwa.

W związku z powyższym łącznie $12 \%$ ankietowanych jest w stanie ryzykować uruchomienie własnej działalności gospodarczej z dziedziny rachunkowości mimo braku należytego przygotowania zawodowego, świadomości złożoności problemów występujących w pracy zawodowej i odpowiedzialności, jaka spoczywa na osobach zajmujących się rachunkowością. Może to oznaczać nieuczciwość intelektualną, a więc zagrożenie postępowaniem niezgodnym z etyką środowiska zawodowego.

Kodeks wprowadza określone zasady postępowania osoby zajmującej się rachunkowością w relacjach z osobami, jednostkami i instytucjami powiązanymi $\mathrm{z}$ nią zawodowo. W celu ich spełnienia powinno dbać się o dobro imienia zawodu, starać się o nienaruszanie interesu publicznego, opierać na bezinteresowności, wspólnym zaangażowaniu i wymianie doświadczeń z zachowywaniem służbowych relacji. Czy student, mając do wyboru dwie strategie postępowania (etycznego lub nie), będzie skłaniał się do tej, która przyniesie mu różne korzyści (np. materialne), bez względu na konsekwencje? Kolejne pytanie dotyczyło skłonności studentów do przyjmowania prezentów od klienta w zależności od ich wartości. W stosunkach z kontrahentami firmy dość często uznają, iż przyjmowanie prezentów lub innych świadczeń przez pracowników może powodować sytuacje postrzegane jako próba skłaniania do ofiarowania darczyńcy pewnych korzyści (Klimek, 2014: 222). Za działanie jednoznacznie nieetyczne, oznaczające przyjęcie korzyści majątkowych, uznano w badaniu przyjęcie prezentu bez względu na jego wartość (zob. Tabela 5).

Na pytanie o przyjęcie prezentów od klienta około 63\% ankietowanych odpowiedziało „Tak, ale tylko o małej wartości”, natomiast około $27 \%$ „Nie”. Uwzględniając długość stażu zawodowego, największy odsetek odpowiedzi „Tak” zanoto- 
wano w grupie osób deklarującej brak stażu (około 74\%) i do 6 miesięcy (65\%). W pozostałych grupach odsetek ten przekraczał $50 \%$. W przypadku odpowiedzi negatywnej największy odsetek zanotowano wśród osób deklarujących staż od 6 miesięcy do roku (około 37\%) i powyżej roku i (około 32\%). Niestety, 16 osób (około 10\% ogółu respondentów) udzieliło odpowiedzi „Tak, bez względu na wartość prezentu". Analiza odpowiedzi wskazuje największy ich odsetek w grupie o stażu do 6 miesięcy (około 12\%), najniższy zaś w grupie deklarującej brak stażu (około 7\%).

Tabela 5. Czy przyjęłabyś/przyjąłbyś prezenty od klienta firmy za wykonywaną pracę?

\begin{tabular}{|c|c|c|c|c|c|c|c|c|}
\hline \multirow{3}{*}{ Staż pracy } & \multicolumn{6}{|c|}{ Odpowiedzi } & \multirow{2}{*}{\multicolumn{2}{|c|}{ Ogółem }} \\
\hline & \multicolumn{2}{|c|}{$\begin{array}{c}\text { Tak, ale } \\
\text { tylko o malej } \\
\text { wartości }\end{array}$} & \multicolumn{2}{|c|}{$\begin{array}{c}\text { Tak, bez } \\
\text { względu } \\
\text { na wartość }\end{array}$} & \multicolumn{2}{|c|}{ Nie } & & \\
\hline & $\begin{array}{c}\text { Liczeb- } \\
\text { ność }\end{array}$ & $\%$ & $\begin{array}{c}\text { Liczeb- } \\
\text { ność }\end{array}$ & $\%$ & $\begin{array}{c}\text { Liczeb- } \\
\text { ność }\end{array}$ & $\%$ & $\begin{array}{c}\text { Liczeb- } \\
\text { ność }\end{array}$ & $\%$ \\
\hline Brak & 40 & 74,07 & 4 & 7,41 & 10 & 18,52 & 54 & 100 \\
\hline Do 6 miesięcy & 11 & 64,71 & 2 & 11,76 & 4 & 23,53 & 17 & 100 \\
\hline Od 6 miesięcy do roku & 10 & 52,63 & 2 & 10,53 & 7 & 36,84 & 19 & 100 \\
\hline Powyżej roku & 42 & 56,76 & 8 & 10,81 & 24 & 32,43 & 74 & 100 \\
\hline Ogółem & 103 & 62,80 & 16 & 9,76 & 45 & 27,44 & 164 & 100 \\
\hline
\end{tabular}

Uzyskane wyniki wskazują, że zdecydowana większość respondentów, niezależnie od deklarowanego stażu pracy czy jego braku, wykazuje gotowość przyjęcia prezentu od klientów. Należy tutaj podkreślić, że autorzy ankiety nie podali założenia, że przyjmowanie drobnych prezentów mieści się w ramach standardowych procedur przyjętych w organizacji. Nie można więc takich działań ocenić jednoznacznie jako etyczne lub nieetyczne. Ważne, aby studenci mieli świadomość, że przyjęte korzyści nie mogą być wynikiem nadużywania stanowiska w ich prywatnym interesie, ukrytą formą płatności powodującą uzależnienie ekonomiczne jednej osoby od drugiej. Niemniej jednak część respondentów (10\%) byłaby skłonna postępować niezgodnie z prawem w zamian za uzyskanie korzyści majątkowych, bez względu na ich wartość. Jest to przykład nieetycznego zachowania i łamania zasad obiektywizmu oraz właściwego postępowania w relacjach z osobami, jednostkami, instytucjami powiązanymi z taką osobą zawodowo. Zasady te są niezbędne w pracy osoby zajmującej się rachunkowością, tworzącej wizerunek zawodu zaufania publicznego. W przypadku tej grupy respondentów takie postawy mogą oznaczać realizację osobistych korzyści kosztem interesu pracodawcy, skłonność pracownika do ustępstw na rzecz osób trzecich oraz niepożądane ich oddziaływanie na osądy o charakterze zawodowym lub gospodarczym. 
Kolejne pytanie ankiety dotyczyło zrealizowania zlecenia klienta prywatnie, poza firmą (zob. Tabela 6).

Tabela 6. Czy jako pracownik przyjęłabyś/przyjąłbyśs realizację zlecenia klienta prywatnie, poza firmą?

\begin{tabular}{|c|c|c|c|c|c|c|c|c|}
\hline \multirow{3}{*}{ Staż pracy } & \multicolumn{6}{|c|}{ Odpowiedzi } & \multirow{2}{*}{\multicolumn{2}{|c|}{ Ogółem }} \\
\hline & \multicolumn{2}{|c|}{$\begin{array}{c}\text { Tak, w ramach } \\
\text { pomocy }\end{array}$} & \multicolumn{2}{|c|}{ Tak, odplatnie } & \multicolumn{2}{|c|}{ Nie } & & \\
\hline & $\begin{array}{c}\text { Liczeb- } \\
\text { ność }\end{array}$ & $\%$ & $\begin{array}{c}\text { Liczeb- } \\
\text { ność }\end{array}$ & $\%$ & $\begin{array}{c}\text { Liczeb- } \\
\text { ność }\end{array}$ & $\%$ & $\begin{array}{c}\text { Liczeb- } \\
\text { ność }\end{array}$ & $\%$ \\
\hline Brak & 21 & 38,89 & 7 & 12,96 & 26 & 48,15 & 54 & 100 \\
\hline Do 6 miesięcy & 7 & 41,18 & 5 & 29,91 & 5 & 29,41 & 17 & 100 \\
\hline Od 6 miesięcy do roku & 8 & 42,10 & 2 & 10,53 & 9 & 47,37 & 19 & 100 \\
\hline Powyżej roku & 19 & 25,68 & 12 & 16,22 & 43 & 58,11 & 74 & 100 \\
\hline Ogółem & 55 & 33,54 & 26 & 15,85 & 83 & 50,61 & 164 & 100 \\
\hline
\end{tabular}

Źródło: opracowanie własne

Udzielone odpowiedzi potwierdzają skłonność części ankietowanych studentów do tworzenia nieformalnych związków z klientem, bycia nielojalnym wobec pracodawcy i zawodu, innymi słowy - negatywne relacje $z$ osobami lub jednostkami powiązanymi z nimi zawodowo. Z analizy danych zawartych w Tabeli 6 wynika, że około $51 \%$ respondentów nie przyjęłoby oferty klienta, około $34 \%$ przyjęłoby, ale w ramach pomocy, a więc nieodpłatnie. Około 16\% (26 osób) przyjęłoby ofertę klienta za wynagrodzeniem. Uwzględniając długość stażu zawodowego, dominują osoby z niskim stażem (około 30\%) lub stażem powyżej roku (około 16\%). Oznacza to postawę indywidualnej chęci zdobycia dodatkowego, nielegalnego wynagrodzenia, świadczy o postępowaniu na niekorzyść pracodawcy, we własnym prywatnym interesie. Według kodeksu postępowanie etyczne nakazuje unikanie tego typu sytuacji i działań.

Zgodnie z KZEwR osoba wykonująca zawód w dziedzinie rachunkowości powinna zachować tajemnicę zawodową oraz odpowiadać za przygotowywane i prezentowane informacje niezbędne do właściwej oceny zaistniałych sytuacji. Kolejne pytania miały na celu zweryfikowanie, czy można mieć zaufanie do osoby, jej postaw i zachowań, a równocześnie do rezultatów pracy, w tym informacji przekazywanej różnym interesariuszom.

Najpierw ankietowanych zapytano o zachowanie tajemnicy zawodowej na temat kontrahentów i innych aspektów działalności po zmianie miejsca pracy. Strukturę odpowiedzi przedstawia Tabela 7.

Zasada zachowania tajemnicy zawodowej oznacza nierozpowszechnianie informacji wewnętrznych, uzyskanych w wyniku powiązań zawodowych i gospodarczych, których ujawnianie nie jest obowiązkowe w świetle prawa. Zasada ta obowiązuje także po ustaniu formalnych powiązań z daną jednostką. Zdecy- 
dowana większość respondentów (około 91\%) wybrała zachowanie tajemnicy zawodowej. W tej grupie znalazły się zarówno osoby deklarujące brak stażu (około $89 \%$ pozytywnych odpowiedzi), jak i legitymujące się różnym stażem zawodowym. Zdecydowanie mniej ankietowanych, około 9\%, wybrało odpowiedź negatywną, oznaczającą skłonność do nieetycznych zachowań. W przypadku tej grupy najwyższy odsetek dotyczy respondentów bez stażu zawodowego (około 11\%) i deklarujących staż do 6 miesięcy (około 12\%).

\section{Tabela 7. Czy po zmianie pracy zachowałabyś/zachowałbyś tajemnicę zawodową na temat kontrahentów i innych aspektów działalności poprzedniego pracodawcy?}

\begin{tabular}{|l|c|c|c|c|c|c|}
\hline \multirow{2}{*}{ Staż pracy } & \multicolumn{3}{c|}{ Odpowiedzi } & \multicolumn{2}{c|}{ Ogółem } \\
\cline { 2 - 7 } & \multicolumn{3}{|c|}{ Tak } & \multicolumn{2}{c|}{ Nie } & \multicolumn{2}{c|}{} \\
\cline { 2 - 7 } & Liczebność & \% & Liczebność & \% & Liczebność & $\%$ \\
\hline Brak & 48 & 88,89 & 6 & 11,11 & 54 & 100 \\
\hline Do 6 miesięcy & 15 & 88,24 & 2 & 11,76 & 17 & 100 \\
\hline Od 6 miesięcy do roku & 18 & 94,74 & 1 & 5,26 & 19 & 100 \\
\hline Powyżej roku & 68 & 91,89 & 6 & 8,11 & 74 & 100 \\
\hline Ogółem & 149 & 90,85 & 15 & 9,15 & 164 & 100 \\
\hline
\end{tabular}

Źródło: opracowanie własne

Analiza odpowiedzi na kolejne pytanie ankiety (zob. Tabela 8) pozwoliła ocenić, czy studenci będą przestrzegać zasady odpowiedzialności za przygotowywane i prezentowane informacje z zakresu rachunkowości oraz zasady zachowania niezależności w procesie ich przygotowywania.

Tabela 8. Czy w celu pozyskania przez firmę kredytów bankowych czy też innych obcych źródeł finansowania (np. dotacji unijnych) zgodziłabyś/zgodziłbyś się przedstawić w lepszym świetle dane w sprawozdaniu finansowym na temat sytuacji finansowej firmy?

\begin{tabular}{|l|c|c|c|c|c|c|}
\hline \multirow{2}{*}{ Staż pracy } & \multicolumn{3}{c|}{ Odpowiedzi } & \multicolumn{2}{c|}{ Ogółem } \\
\cline { 2 - 7 } & \multicolumn{2}{|c|}{ Tak } & \multicolumn{2}{c|}{ Nie } & \multicolumn{2}{c|}{} \\
\cline { 2 - 7 } & Liczebność & \% & Liczebność & \% & Liczebność & $\%$ \\
\hline Brak & 10 & 18,52 & 44 & 81,48 & 54 & 100 \\
\hline Do 6 miesięcy & 5 & 29,41 & 12 & 70,59 & 17 & 100 \\
\hline Od 6 miesięcy do roku & 6 & 31,58 & 13 & 68,42 & 19 & 100 \\
\hline Powyżej roku & 13 & 17,57 & 61 & 82,43 & 74 & 100 \\
\hline Ogółem & 34 & 20,73 & 130 & 79,27 & 164 & 100 \\
\hline
\end{tabular}

Źródło: opracowanie własne

Zachowanie naruszające normy etyczne, a więc przedstawienie przedsiębiorstwa w lepszym świetle w celu pozyskania obcych źródeł finansowania, zaznaczyło około $21 \%$ ogółu ankietowanych. Uwzględniając kryterium długości stażu zawodowego, celowego zniekształcenia informacji finansowych dokonałoby najwięcej ankietowanych ze stażem od 6 miesięcy do roku (około 32\% tej grupy) oraz 
do 6 miesięcy (około 29\% tej grupy). W przypadku braku stażu i stażu powyżej roku odpowiedzi „Tak” udzieliło około $18 \%$ badanych z każdej z tych grup. Zdecydowana większość, nieco ponad 79\% ogółu respondentów, na zadane pytanie odpowiedziała negatywnie, co należy ocenić pozytywnie, jako zachowanie zgodne ze standardami zawodowymi.

Kolejne pytanie dotyczyło skłonności do fałszowania dokumentów księgowych przez złożenie podpisu za inną osobę (zob. Tabela 9). Bez względu na długość doświadczenia zawodowego lub jego brak zdecydowana większość studentów - nieco ponad $92 \%$ ogółu respondentów - odpowiedziała negatywnie. Na tak postawione pytanie około $8 \%$ ankietowanych odpowiedziało pozytywnie, a to oznacza ich skłonność do działań niezgodnych z prawem. Dominują tutaj osoby deklarujące brak doświadczenia zawodowego (nieco ponad 9\% ogółu studentów w tej grupie) oraz staż powyżej roku ( $8 \%$ ogółu w tej grupie).

Tabela 9. Czy złożyłabyś/złożyłbyś podpis za inną osobę na dokumencie księgowym?

\begin{tabular}{|l|c|c|c|c|c|c|}
\hline \multirow{2}{*}{ Staż pracy } & \multicolumn{3}{c|}{ Odpowiedzi } & \multicolumn{2}{c|}{ Ogólem } \\
\cline { 2 - 7 } & \multicolumn{2}{|c|}{ Tak } & \multicolumn{2}{c|}{ Nie } & \multicolumn{2}{c|}{} \\
\cline { 2 - 7 } & Liczebność & \% & Liczebność & \% & Liczebność & $\%$ \\
\hline Brak & 5 & 9,26 & 49 & 90,74 & 54 & 100 \\
\hline Do 6 miesięcy & 1 & 5,88 & 16 & 94,12 & 17 & 100 \\
\hline Od 6 miesięcy do roku & 1 & 5,26 & 18 & 94,74 & 19 & 100 \\
\hline Powyżej roku & 6 & 8,11 & 68 & 91,89 & 74 & 100 \\
\hline Ogółem & 13 & 7,93 & 151 & 92,07 & 164 & 100 \\
\hline
\end{tabular}

Źródło: opracowanie własne

Kolejnym rozpatrywanym zagadnieniem była ocena motywów wpływających na nieetyczne postępowanie (zob. tabela 10). Respondenci dokonywali oceny, wykorzystując pięciopunktową skalę (siła wpływu: 1 - brak, 2 - mała, 3 - średnia, 4 - duża, 5 - bardzo duża).

Tabela 10 przedstawia oceny poszczególnych motywów wpływających na nieetyczne postępowanie. Biorąc pod uwagę średnią wszystkich ocen $(2,98)$, respondenci ocenili, że podane motywy przeciętnie wpływają na nieetyczne zachowania. Średni wpływ na nieetyczne postępowanie ma chęć utrzymania pracy oraz brak etyki zawodowej przełożonych (średnia w obu przypadkach wyniosła 3,24). Nieco niżej zostały ocenione takie motywy jak: presja kierownictwa na wyniki (średnia 3,09), chęć dużego zysku dla siebie (średnia 3,02) oraz chęć ukrycia własnych błędów (średnia 2,99 ). W przypadku wymienionych działań współczynniki asymetrii są ujemne, lecz stosunkowo niewielkie, co oznacza, że oceny studentów równomiernie rozłożyły się wokół średniej arytmetycznej. Poniżej średniej wszystkich ocen znalazły się oceny takich motywów jak chęć przypodobania się szefowi (średnia 2,86), nielegalny zysk bez konsekwencji (średnia 2,80), obniże- 
nie zobowiązań podatkowych (średnia 2,61). Współczynniki asymetrii są w tym przypadku dodatnie, co oznacza lewostronny rozkład ocen, czyli studenci najczęściej oceniali dane motywy poniżej średniej arytmetycznej. Dla wszystkich ocen dominanta i mediana wyniosły 3 , z wyjątkiem oceny motywu nielegalny zysk bez konsekwencji, dla której dominanta wyniosła 1. Potwierdza to początkowe stwierdzenie, że według respondentów podane motywy mają średni wpływ na nieetyczne postępowanie. Współczynnik zmienności zawiera się w przedziale 40,62-54,19\%, jest wysoki i świadczy o dużym rozproszeniu ocen. Powyższa analiza może skłaniać do stwierdzenia, że istnieją inne motywy, niewymienione przez autorów badania, które wpływają na nieetyczne postępowanie.

Tabela 10. Charakterystyka liczbowa wpływu określonych motywów na nieetyczne postępowanie

\begin{tabular}{|c|c|c|c|c|c|c|}
\hline \multirow[b]{2}{*}{ Motywy } & \multicolumn{6}{|c|}{ Oceny studentów - podstawowe miary } \\
\hline & 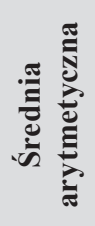 & 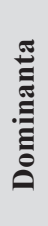 & 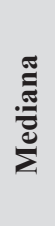 & 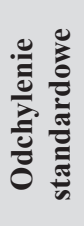 & 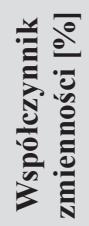 & 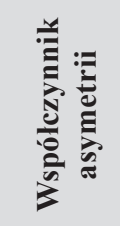 \\
\hline Chęć utrzymania pracy & 3,24 & 3 & 3 & 1,33 & 40,97 & $-0,1682$ \\
\hline Brak etyki zawodowej przełożonych & 3,24 & 3 & 3 & 1,34 & 41,40 & $-0,2319$ \\
\hline Presja kierownictwa na wyniki & 3,09 & 3 & 3 & 1,26 & 40,62 & $-0,1387$ \\
\hline Chęć dużego zysku dla siebie & 3,02 & 3 & 3 & 1,28 & 42,36 & $-0,0465$ \\
\hline Chęć ukrycia własnych błędów & 2,99 & 3 & 3 & 1,33 & 44,47 & $-0,0250$ \\
\hline Chęć przypodobania się szefowi & 2,86 & 3 & 3 & 1,25 & 43,78 & 0,1468 \\
\hline Nielegalny zysk bez konsekwencji & 2,80 & 1 & 3 & 1,52 & 54,19 & 0,1684 \\
\hline Obniżenie zobowiązań podatkowych & 2,61 & 3 & 3 & 1,26 & 48,39 & 0,2286 \\
\hline Razem & 2,98 & 3 & 3 & 1,34 & 44,97 & $-0,0081$ \\
\hline
\end{tabular}

Źródło: opracowanie własne

W dalszej kolejności respondenci ocenili czynniki wpływające na ich etyczne postępowanie (zob. Tabela 11). Ankietowani oceniali wpływ określonych czynników również w pięciopunktowej skali (1 - bardzo mały wpływ; 2 - mały wpływ; 3 - średni wpływ; 4 - duży wpływ; 5 - bardzo duży wpływ).

Tabela 11 przedstawia szczegółowe oceny poszczególnych czynników wpływających na etyczne postępowanie. Średnia wszystkich ocen wynosi 3,82. Bardzo wysoko (średnie powyżej 4) respondenci ocenili, że na postępowanie etyczne wpływa wychowanie (średnia 4,60), własne poglądy i szacunek do samego siebie (średnia 4,59) oraz edukacja (średnia 4,06). Nieco niżej (średnie powyżej 3,5) oceniono wpływ takich czynników jak: obawa przed konsekwencjami karno-skarbowymi (średnia 3,98), autory tety (średnia 3,76) oraz możliwość utraty wysokich zarobków (średnia 3,66). Najniżej zostały ocenione religia (średnia 3,26) 
oraz postępowanie koleżanek i kolegów (średnia 2,61). We wszystkich przypadkach dominanta i mediana były wyższe od średniej arytmetycznej. Wskaźniki zmienności wskazują, że im niżej oceniany był czynnik, tym odpowiedzi studentów były mniej skoncentrowane wokół średniej. Wysokie i ujemne wskaźniki asymetrii (od $-2,41$ do $-0,21$ ) oznaczają prawostronny rozkład ocen, czyli studenci najczęściej oceniali dane czynniki powyżej średniej arytmetycznej, z wyjątkiem oceny czynnika, jakim jest postępowanie koleżanek i kolegów, dla którego współczynnik asymetrii był dodatni. Ten czynnik studenci oceniali poniżej średniej.

Tabela 11. Charakterystyka liczbowa wpływu określonych czynników na etyczne postępowanie

\begin{tabular}{|c|c|c|c|c|c|c|}
\hline \multirow[b]{2}{*}{ Czynniki } & \multicolumn{6}{|c|}{ Oceny studentów - podstawowe miary } \\
\hline & 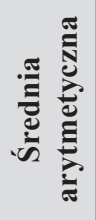 & 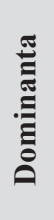 & 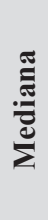 & 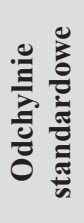 & 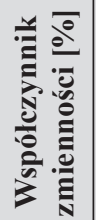 & 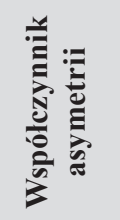 \\
\hline Wychowanie & 4,60 & 5 & 5 & 0,79 & 17,23 & $-2,2676$ \\
\hline Własne poglądy i szacunek dla samego siebie & 4,59 & 5 & 5 & 0,80 & 17,48 & $-2,4092$ \\
\hline Edukacja & 4,06 & 5 & 4 & 0,99 & 24,35 & $-0,9694$ \\
\hline $\begin{array}{l}\text { Obawa przed konsekwencjami karnymi } \\
\text { i skarbowymi }\end{array}$ & 3,98 & 5 & 4 & 1,10 & 27,77 & $-0,9117$ \\
\hline Autorytety & 3,76 & 4 & 4 & 1,08 & 28,74 & $-0,6232$ \\
\hline Możliwość utraty wysokich zarobków & 3,66 & 4 & 4 & 1,08 & 29,64 & $-0,4723$ \\
\hline Religia & 3,26 & 5 & 3 & 1,41 & 43,38 & $-0,2143$ \\
\hline Postępowanie koleżanek i kolegów & 2,61 & 3 & 3 & 1,13 & 43,12 & 0,1692 \\
\hline Razem & 3,82 & 5 & 4 & 1,23 & 32,20 & $-0,7712$ \\
\hline
\end{tabular}

Źródło: opracowanie własne

Analiza odpowiedzi pokazuje, że do czynników, którym studenci przypisali istotne znaczenie, zaliczono wychowanie oraz własne poglądy i szacunek do samego siebie. Są to więc czynniki będące efektem określania własnej tożsamości, oddziaływań wychowawczych w dzieciństwie, relacji między nimi a rodzicami i innymi osobami dorosłymi oraz własnych zachowań, na jakie było przyzwolenie w przeszłości. Można zatem stwierdzić, że to czynniki osobiste, związane z systemem wartości wynikającym $z$ tradycji rodzinnej, edukacji i autorytetów, mają decydujący wpływ na ich poglądy w kontekście etyki zawodowej w rachunkowości. Oprócz czynników indywidualnych respondenci wskazali również na czynniki prawne (obawa przed konsekwencjami karnymi i skarbowymi), a także materialne (utrata zarobków). 
Kolejnym etapem badania było ustalenie, co zdaniem ankietowanych przyczyniłoby się do poprawy zachowań etycznych w zakresie rachunkowości. Na 164 wypełnione ankiety odpowiedzi na to otwarte pytanie udzieliło tylko 72 respondentów, co stanowi około $44 \%$ ankietowanych. Odpowiedzi ankietowanych były bardzo zróżnicowane. Najczęściej respondenci wskazywali, że do poprawy zachowań etycznych przyczyniłyby się:

1) edukacja oraz właściwe wychowanie dzieci i młodzieży, wzrost znaczenia autorytetów, wzorce moralne,

2) zwiększenie odpowiedzialności karnej, a także wysokie kary za zachowania nieetyczne i niezgodne z prawem,

3) czynniki materialne w postaci wyższego wynagrodzenia i nagród, lepsze warunki pracy,

4) pozytywne relacje z pracodawcami (rozmowa, współpraca, chęć zrozumienia pracownika przez szefa, wzajemny szacunek), dobra atmosfera w firmie, wymagania przełożonego, częste kontrole działań,

5) kampanie społeczne uświadamiające poprawne zachowania etyczne w społeczeństwie, presja społeczeństwa,

6) własne wartości.

Reasumując, czynniki te i działania koncentrują się głównie wokół indywidualnych celów studentów. Wypowiedzi te wskazują na potrzebę propagowania w ich środowisku zawartych w KZEwR zasad etycznych i profesjonalnego zachowania.

Na pytanie, czy w trakcie studiów były omawiane problemy etyczne, około 45\% (tj. 73 respondentów) udzieliło negatywnej odpowiedzi. Jeśli odpowiedź była pozytywna, ankietowani wskazywali przedmiot, na którym były omawiane problemy etyczne. Tymi przedmiotami były: kreatywna księgowość i fałszowanie sprawozdań finansowych, audyt wewnętrzny, rachunkowość sektora budżetowego, rachunkowość, sprawozdawczość finansowa, rewizja sprawozdań finansowych, doradztwo podatkowe, marketing, ekonomia, prawo, techniki sprzedaży, etyka inżyniera, etyka w zarządzaniu, etyka w biznesie, rachunkowość zarządcza, etyka zawodowa, zarządzanie zmianą. Wypowiedzi te wskazują na potrzebę propagowania w środowisku młodzieży akademickiej zasad etycznych i profesjonalnego zachowania zawartych w KZEwR.

\section{Wnioski}

Podsumowując, można stwierdzić, że zawodowa etyka w rachunkowości stanowi obszar badań ważny zarówno ze względów poznawczych, jak i praktycznych. Przeprowadzone analizy postaw etycznych studentów skłaniają do następujących wniosków: 
1) etyka kodeksowa, w obecnych czasach promowana przez etykę biznesu, określa normy etyczne dla świata biznesu, a użyteczność kodeksów jest tym większa, im bardziej osoby, do których są kierowane, znają je i się z nimi identyfikują;

2) problematyka deontologii zawodów związanych z rachunkowością jest w ostatnich latach przedmiotem zainteresowania zarówno teoretyków, jak i praktyków; ujęte w KZEwR normy etyki zawodowej są efektem dociekań naukowych oraz doświadczeń zgromadzonych w praktyce zawodowej księgowych;

3) podstawowe wartości etyczne mogą być różnie interpretowane, zachowania ludzi warunkują bowiem zarówno czynniki egzo-, jak i endogeniczne; konieczne są więc porównania rzeczywistych kwestii moralności osób zajmujących się rachunkowością z oczekiwanymi zasadami etyki i postępowania środowiska księgowych; spełnianie wymagań środowiskowych stanowi o różnicy między etycznie złym a dobrym wykonywaniem zawodu.

Jak wynika z badań, studenci wskazali na powszechnie znane ogólne wartości etyczne. W postępowaniu uwzględniają zarówno własne osądy moralne (postępowanie zgodne z własnym sumieniem), jak i łączenie etyki z respektowaniem norm, wzorców, które są podane w KZEwR jako niezbędne w codziennej działalności zawodowej. Jednak nie zawsze indywidualne zachowania studentów są zgodne z tym, co uważa się za właściwe i etyczne według standardów środowiska zawodowego. Wyraźnie daje się zauważyć, że studenci kierują się własnymi zasadami etycznymi, nawet jeśli naruszają prawo, wybierają zachowania, kierując się własnym interesem. Uzyskane wyniki badań ujawniają skłonność części ankietowanych do różnego rodzaju działań nieetycznych, zagrażających realizacji ogólnych zasad etyki w rachunkowości, zarówno wśród osób zamierzających pracować, jak i deklarujących staż w zawodach księgowych. W toku badania ustalono, że respondenci przywiązują szczególną uwagę do wychowania oraz postępowania w zgodzie z własnymi poglądami i do szacunku do samego siebie, a to oznacza doniosłą rolę własnych osądów i wartości moralnych jako motywatorów określonych zachowań etycznych. Badanie wskazuje na motywy skłaniające do nieetycznych zachowań. Największy wpływ na nieetyczne postępowanie mają czynniki związane z praktyką zawodową, łączone jednak z osobistą perspektywą, na przykład zagrożeniem utraty pracy, względami materialnymi. Działania nieetyczne i niezgodne z prawem osób zajmujących się rachunkowością podważają zaufanie publiczne do zawodu księgowego i do informacji pochodzących z systemu rachunkowości.

Przeprowadzone badanie ukazuje kierunki proponowanych przez studentów działań sprzyjających upowszechnianiu zasad etycznego postępowania. Opowiadają się oni za edukacją, właściwym wychowaniem dzieci i młodzieży, oczekują kontroli i kar za naruszanie wymogów etycznych, a także motywacji do działań etycznych za pomocą wynagradzania. Nie wskazują jednak w wolnych wypowiedziach na czynniki egzogeniczne, takie jak normy prawa bilansowego oraz normy 
regulujące różne aspekty działalności gospodarczej, a także wynikające z kodeksów środowiskowych.

Aby upowszechniać zasady etyki zawodowej i pozytywnie oddziaływać na postawy etyczne w środowiskach studenckich, w edukacji przyszłych księgowych należy podawać przykłady opisujące dylematy etyczne i prowadzić dyskusje w zakresie:

1) przestrzegania przepisów prawa, uniwersalnych norm etycznych oraz specjalnych norm i zasad etycznych w zawodzie, propagowania norm środowiskowych,

2) informowania o złożoności problemów natury etycznej w pracy zawodowych księgowych, procedurach zachowania poufności informacji,

3) zachowania właściwych relacji z osobami powiązanymi zawodowo, opartych na bezinteresowności, uczciwości, niezależności, działaniu w sposób kompetentny, obiektywny i rzetelny.

Należy podkreślić, że przeprowadzone badanie ma charakter pilotażowy. Podstawowe ograniczenie badawcze to liczba pytań ujętych w kwestionariuszu, liczebność próby oraz deklarowane przez studentów doświadczenie zawodowe w rachunkowości. Wartościowsze byłoby ukazanie tego problemu w zależności od miejsca zatrudnienia studenta (np. biuro rachunkowe, wielka czwórka, firma produkcyjna, dział księgowości itp.) lub badanie porównawcze w tym zakresie między krajami.

W zasadniczym badaniu naukowym autorki zwrócą uwagę na:

1) nurt behawioralny w analizie osobowości studentów i ich postaw, motywów zachowań i podejmowanych decyzji, rozumienia i stosowania norm środowiskowych;

2) teorię podejmowania decyzji, która za podstawowe kryterium wyboru przyjmuje zwykle maksymalizowanie preferencji lub użyteczności decydenta; nie wyklucza ona odwoływania się także do innych motywów, takich jak wpływ czynników egzogenicznych na postępowanie etyczne badanych.

\section{Bibliografia}

Brinkmann J. (2002), Business and Marketing Ethics as Professional Ethics. Concepts, Approaches and Typologies, „Journal of Business Ethics”, November/December, t. 41, nr 1/2, s. 159-177.

Cagle J.A.B., Baucus M.S. (2006), Case Studies of Ethics Scandals: Effects on Ethical Perceptions of Finance Students, „Journal of Business Ethics”, t. 64, cz. 3, s. 213-229, http://doi. org/10.1007/s10551-005-8503-5

Chwistecka-Dudek H. (2014), Koncepcja etyki w procesach zarządzania przedsiębiorstwem, Wyższa Szkoła Biznesu w Dąbrowie Górniczej, Dąbrowa Górnicza.

Czarencki P. (2008), Dylematy etyczne wspótczesności, Wydawnictwo Difin, Warszawa.

Derlukiewicz K. (2014), Etyka w rachunkowości, [w:] W. Baran (red.), Podstawy rachunkowości. Sprawozdanie finansowe. Zasady. Etyka, Wydawnictwo Difin, Warszawa, s. 306-313. 
Elias R.Z., Farag M. (2010), The relationship between accounting students' love of money and their ethical perception, „Managerial Auditing Journal”, t. 25, nr 3, s. 269-281, http://doi. org/10.1108/02686901011026369

Emerson T.L.N., Conroy S.J., Stanley C.W. (2007), Ethical Attitudes of Accountants: Recent Evidence from a Practitioners' Survey, „Journal of Business Ethics”, t. 71, cz. 1, s. 73-87, http:// doi.org/10.1007/s10551-006-9125-2

Fischer M., Marsh T., Hunt G.L. (2013), Attitudes of Students and Practitioners Regarding Ethical Acceptability of Accounting Transactions, „Journal of Learning in Higher Education”, Spring, t. 9, cz. 1, s. 93-104.

Garstka M. (2014), Etyka zawodowa w rachunkowości, „Annales. Etyka w Życiu Gospodarczym”, t. 17 , nr 1, s. 61-72.

Gasparski W. (2012), Kodeksy i programy etyczne, [w:] Gasparski W. (red.), Biznes, etyka, odpowiedzialność, Wydawnictwa Profesjonalne PWN, Warszawa, s. 233-248.

Godlewska J., Fołta T. (2017), Zaawansowana rachunkowość finansowa z elementami etyki zawodowej i technologii IT, Stowarzyszenie Księgowych w Polsce, Zarząd Główny, Instytut Certyfikacji Zawodowej Księgowych, Warszawa.

Gurvitsh N., Alver J., Alver L. (2017), On the role and place of business ethics on the modern business world - evidence from Estonia, „Zeszyty Teoretyczne Rachunkowości”, t. 93(140), s. 79-95, http://doi.org/10.5604/01.3001.0010.3190

Jaijairam P. (2017), Ethics in Accounting, ,Journal of Finance and Accountancy”, nr 23, s. 1-13.

Karczewski L. (2008), Etyka biznesu. Kulturowe uwarunkowania, Politechnika Opolska, Opole.

Karmańska A. (2005), Etyka w dydaktyce rachunkowości, „Zeszyty Teoretyczne Rachunkowości”, t. 26(82), s. 138-165.

Karmańska A. (2007), Bezpieczeństwo biznesu, dylematy etyczne i profesjonalizm zawodu księgowego, [w:] T. Cebrowska, A. Kowalik, R. Stępień (red.), Rachunkowość wczoraj, dziś, jutro, Stowarzyszenie Księgowych w Polsce, Zarząd Główny, COSZ, Warszawa, s. 397-415.

Karmańska A. (2016), Eseje wokół zagadnień etyki, [w:] Karmańska A. (red.), Etyka zawodowa w rachunkowości, Stowarzyszenie Księgowych w Polsce, Zarząd Główny, Instytut Certyfikacji Zawodowej Księgowych, Warszawa, s. 27-86.

Klimek J. (2014), Etyka biznesu. Teoretyczne założenia, praktyka zastosowań, Wydawnictwo Difin, Warszawa.

Kodeks zawodowej etyki w rachunkowości (2007), Stowarzyszenie Księgowych w Polsce, Zarząd Główny, Warszawa.

Kozak P. (2010), Postawy etyczne studentów Wydziału Nauk Ekonomicznych i Zarządzania UMK w Toruniu, „Rachunkowość”, nr 10, s. 54-59.

Kutera M., Hołda A., Surdykowska S. T. (2006), Oszustwa księgowe teoria i praktyka, Wydawnictwo Difin, Warszawa.

Kuzior A. (2017), Etyka zarzadzania i etyka biznesu. Zagadnienia podstawowe, [w:] Kuzior A. (red.), Etyka biznesu i zrównoważony rozwój. Interdyscyplinarne studia teoretyczno-empiryczne nr 2. Wokót podstawowych zagadnień wspótczesności, Śląskie Centrum Etyki Biznesu i Zrównoważonego Rozwoju, Zabrze, s. 69-85.

Lewicka-Strzałecka A. (1999), Etyczne standardy firm i pracowników, Wydawnictwo Instytutu Filozofii i Socjologii Polskiej Akademii Nauk, Warszawa.

Lipińska E. (2016), Kodeks etyki w budowaniu wizerunku pracy biura rachunkowego, „Studia Ekonomiczne. Zeszyty Naukowe Uniwersytetu Ekonomicznego w Katowicach", nr 285, s. $228-237$.

Maruszewska E.W. (2014), Współczesna rachunkowość a etyka zawodowa w polskiej literaturze z zakresu rachunkowości finansowej, „Studia Ekonomiczne. Zeszyty Naukowe Uniwersytetu Ekonomicznego w Katowicach”, nr 164, s. 109-120. 
Micewski E.R., Troy C. (2007), Business Ethics - Deontologically Revisited, „Journal of Business Ethics", t. 72, cz. 1, s. 17-25, http://doi.org/10.1007/s10551-006-9152-z

Micherda B., Świetla K. (2013), Wspótczesna rachunkowość. Wybrane problemy metodologiczne, Wydawnictwo Difin, Warszawa.

Nowak M. (2018), Etyka rachunkowości w spojrzeniu polskich badaczy. Metaanaliza monografii krajowych, „Prace Naukowe Uniwersytetu Ekonomicznego we Wrocławiu”, nr 506, s. 93-104, http://doi.org/10.15611/pn.2018.506.09

Piechocka-Kałużna A. (2014), Czy etyka jest panaceum na wiarygodność wyników przedsiębiorstw prezentowanych $w$ sprawozdaniach finansowych?, ,Zeszyty Naukowe Uniwersytetu Szczecińskiego”, nr 803, „Finanse, Rynki Finansowe, Ubezpieczenia”, nr 66, s. 443-456.

Pratley P. (1998), Etyka w biznesie, Gebethner i Ska, Warszawa.

Rybak M. (2004), Etyka menedżera - społeczna odpowiedzialność przedsiębiorstwa, Wydawnictwo Naukowe PWN, Warszawa.

Sawicki K. (2013), Obiektywizm i niezależność biegtych rewidentów i księgowych wedlug kodeksów etyki zawodowej i przepisów prawa, „Zeszyty Naukowe Uniwersytetu Szczecińskiego”, nr 765, „Finanse, Rynki Finansowe i Ubezpieczenia”, nr 61, s. 581-594.

Szulczewski G. (2012), Rozważania o miejscu etyki i moralności w teorii i praktyce gospodarczej, Szkoła Główna Handlowa - Oficyna Wydawnicza, Warszawa.

Tyszka T., Macko A. (2012), Oceny i decyzje moralne, [w:] W. Gasparski (red.), Biznes, etyka, odpowiedzialność, Wydawnictwa Profesjonalne PWN, Warszawa, s. 319-339.

Voss G. (2016), Ksztattowanie norm etycznych a odpowiedzialność zawodowa księgowych, Wydawnictwo Uczelniane Uniwersytetu Technologiczno-Przyrodniczego w Bydgoszczy, Bydgoszcz.

Wala F. (2016), Od wydawcy, [w:] A. Karmańska (red.), Etyka zawodowa w rachunkowości, Stowarzyszenie Księgowych w Polsce, Zarząd Główny, Instytut Certyfikacji Zawodowej Księgowych, Warszawa, s. 9-10.

Wołoszyn-Spirka W., Krause E. (2012), Wybrane zagadnienia etyki doradcy zawodowego, Wydawnictwo Uniwersytetu Kazimierza Wielkiego, Bydgoszcz.

Zadroga A. (2009), Współczesne ujęcia etyki biznesu w Polsce. Próba oceny z perspektywy teologii moralnej, Wydawnictwo Katolickiego Uniwersytetu Lubelskiego, Lublin.

Zuchewicz J. (2008), Etyka i wartości zawodowe księgowego w teorii i praktyce, ,Zeszyty Naukowe Uniwersytetu Szczecińskiego”, nr 493, „Finanse, Rynki Finansowe, Ubezpieczenia”, nr 9, s. 551-559.

Żuraw P. (2012), Idea Kodeksu Zawodowej Etyki w Rachunkowości rekomendowanego przez Stowarzyszenie Księgowych w Polsce, ,Annales. Etyka w Życiu Gospodarczym”, t. 15, nr 1, s. $121-130$.

\section{Professional ethics of accountants from the perspective of students - presentation of survey results}

\footnotetext{
Abstract: Professional ethics is a set of rules and norms determining how - from a moral point of view - representatives of a particular profession should behave. Codes of ethics are a tool for developing ethical principles and values adapted to specific professional groups, including professional accountants. For several years, there has been the Code of Professional Ethics in Accounting (CPEA) to be followed, adopted by the Association of Accountants in Poland. According to the Code, the basic principles for accounting professionals include honesty, objectivity, professional competence and due diligence, maintaining the confidentiality of information, and professional attitude. The research problem is an attempt to answer the question: Do the individual ethical principles and ethical values of students coincide with the ethical principles of the professional community of accountants that
} 
CPEA presents? The aim of the article is to identify moral and potential unethical behaviors among accounting students in the context of the ethical principles of CPEA. To achieve the goal of the article, an empirical study was carried out. The pilot study using the PAPI technique was used in the research process. The quantitative methods were used in the development of the survey results. As results from the research, students pointed to general, well-known ethical values. However, the students' individual behavior is not always consistent with what is considered to be appropriate and ethical according to the standards of the professional environment. It is clearly visible that the students are guided by their own ethical principles, even if they violate the law, make choices to behave following their own interest. The obtained research results reveal the tendency of many respondents towards various kinds of unethical activities that threaten the implementation of general ethics in accounting, both among people who intend to work and those who declare their participation in internships in accounting professions.

Keywords: professional ethics, Code of Professional Ethics in Accounting, accounting, deontological business ethics

JEL: A12, M40, M41

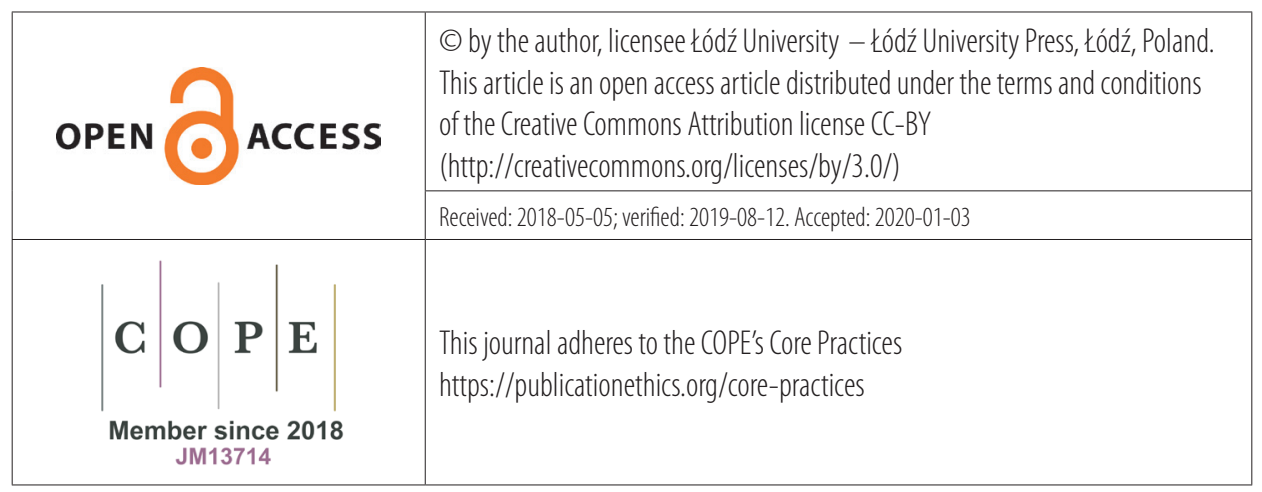

